Z tajnych archiwów radzieckich (4)

MICHA£ GNATOWSKI (Białystok)

\title{
PROBLEMY SZP-ZWZ W REGIONIE BIAŁOSTOCKIM W LATACH 1939-1941 W ŚWIETLE DOKUMENTÓW NKWD (NKGB)
}

Sprawa polskiego podziemia niepodległościowego i oporu wobec radzieckiej polityki na ziemiach włączonych w 1939 r. do ZSRR to temat nowy, tylko częściowo rozpoznany. Jest on stosunkowo słabo udokumentowany w polskich źródłach. Nie to jest jednak głównym powodem niezadowalającego stanu badań nad tym tematem. Istotniejsze były polityczne ograniczenia i zakazy obowiązujące do 1989 r. Historiografia radziecka, wbrew faktom, negowała w ogóle istnienie oporu i podziemia na tych terenach. W ślad za nią również historiografia PRL ograniczała się tylko do ogólnych wzmianek. Ukrywano przy tym niepodległościowy charakter podziemia, eksponując ponad miarę jego antyradziecki, klasowy charakter. Problematyki tej nie podejmowano też szerzej w polskiej historiografii emigracyjnej. Zaważył tym razem utrwalony obiegowy pogląd, że pod radziecką okupacją nie było warunków do prowadzenia walki podziemnej. Sądzono, że panujący w ZSRR system policyjny i totalna propaganda komunistyczna uniemożliwiały prowadzenie takiej działalności.

Podjęte w ostatnich latach w Polsce badania nad tym tematem wykazały, że było inaczej. Udostępniane ostatnio radzieckie źródła w pełni potwierdzają wyniki tych badań i w sposób istotny wzbogacają faktografię. Wynika z nich: po pierwsze - że na obszarch włączonych w 1939 r. do ZSRR istniał szeroko rozbudowany niepodległościowy ruch oporu, który przybrał też formy działalności zbrojnej i partyzantki, i po drugie - podejmowane przez władze radzieckie działania pacyfikacyjne i masowe deportacje ludności na wschód nie zdołały zdławić oporu i dążeń niepodległościowych Polaków. 
Patriotyczna postawa i ofiarność ludności ziem zagarniętych przez ZSRR doprowadziły szybko do powstania grup i organizacji niepodległościowych o różnych orientacjach. Już we wrześniu i październiku 1939 r. z inicjatywy miejscowych aktywistów i działaczy powstawały koła terenowe Stronnictwa Narodowego, Polskiej Partii Socjalistycznej, Stronnictwa Ludowego oraz różne organizacje niepodległościowe nawiązujące do polskich tradycji i wzorów, jak POW, Strzelec i inne. Wkrótce jednak okazało się, że w warunkach radzieckiej okupacji, trudno jest działać w takim rozproszeniu i masowo. Skierowano więc wszystkie siły na organizację i wspieranie konspiracji wojskowej, głównie związanej z SZP i następnie ZWZ. Konspiracja wojskowa opierała się w głównej mierze na niższych rangą oficerach rezerwy oraz podoficerach, zwłaszcza kapralach. Starsi oficerowie zawodowi zostali już w 1939 r. wyeliminowani lub zbiegli w obawie przed aresztowaniami. Według danych NKWD z 28 XII 1939 r. tylko w regionie białostockim aresztowano 262 oficerów ${ }^{1}$.

Białostocczyzna w granicach dowojennego województwa stanowiła w strukturze SZP-ZWZ odrębny okrąg, który wraz z okręgami nowogródzkim i poleskim stanowiły obszar nr 2 (białostocki). Organizowano też, zwłaszcza w okręgu białostockim, obwody, stanowiące strukturę organizacyjną ZWZ na szczeblu powiatu. Trwały też prace nad uruchomieniem niższych szczebli: rejonów i placówek. Radzieckie dokumenty potwierdzają dotychczasowe ustalenia T. Strzembosza, że „rozległość sieci konspiracyjnej w tym terenie przerasta analogiczne sieci ZWZ w Generalnej Guberni, a przygotowania powstańcze są tu wyjątkowo rozwinięte. Inna kwestia, że konspiracja ta, podobnie jak gdzie indziej, prowadzona była bardzo nierozważnie" 2 .

"Nierozwaga" ta wynikała w znacznej części z braku doświadczenia w pracy konspiracyjnej oraz z niedoceniania przeciwnika, który prezentował się stosunkowo "prostacko", wzbudzając niekiedy „rozbawienie" swoim postępowaniem i wyglądem. Nie bez wpływu była też swojska wśród Polaków brawura. Wszystko to oraz masowe aresztowania i deportacje ludności powodowały znaczne straty i mnożyły trudności w działaniu konspiracyjnym. Opór jednak trwał. Rozbijane struktury podziemia były szybko odbu-

1 Narodowe Archiwum Republiki Białoruskiej (NARB) w Mińsku, zesp. 4, spr. 21, t. 1715 , k. 127-129.

2 T. Strzembosz, Partyzantka polska na pótnocno-wschodnich ziemiach II Rzeczypospolitej 1939-1941 (Wileńskie, Nowogródzkie, Grodzieńskie), „Kwartalnik Historyczny”, 1992 , nr 4, s. 27. 
dowywane i chociaż osłabione przetrwały w regionie do wybuchu wojny radziecko-niemieckiej. Do wiosny 1941 r. w wyniku aresztowań aż czterokrotnie zmieniali się komendanci okręgu białostockiego SZP-ZWZ, okręg jednak funkcjonował. Świadczy to o niebywałej ofiarności społeczeństwa i heroicznej postawie konspiratorów. F. Ramotowska wspominając konspirację nadbiebrzańską nie bez żalu stwierdza: „dziś już nie ma tam ludzi takiej klasy” 3 .

Terror w warunkach radzieckiej okupacji nie tylko dławił opór i niszczył wrogów lecz w określonym stopniu wymuszał na podziemiu jego stałe doskonalenie, szukanie nowych, bezpiecznych form konspiracji i działania, doskonalenie umiejętności działania $w$ trudnych warunkach, hartował konspiratorów w walce. Wzbogacał o nowe doświadczenia, niezbędne do przetrwania i skutecznego oporu.

Nie potwierdziła się więc na tych ziemiach teza o dużej skuteczności przeciwdziałania NKWD (NKGB). Przeciwdziałanie to niewątpliwie utrudniało znacznie działalność polskich organizacji podziemnych i powodowało odczuwalne straty lecz nie było w stanie zahamować oporu a tym bardziej go zlikwidować. Z publikowanych radzieckich dokumentów wynika, że większość „wpadek" i strat wynikała w większym stopniu z braku doświadczenia w pracy konspiracyjnej, niż ze skuteczności stosowanych przez NKWD (NKGB) środków. Rozpoznanie podziemia w dużym stopniu opierało się na „wymuszonych zeznaniach" niż na rozpracowaniu konfidencyjnym, pomimo szerokich działań w tym zakresie. Ponadto zdobywane informacje były daleko nieprecyzy jne, informac je o organizacjach obiegowe, ogólnikowe, oparte głównie na dowojennym rozpoznaniu na podstawie przejętych materiałów polskich organizacji i służb specjalnych. Terenowe ogniwa organizacji ogólnokrajowych często traktowane były jako odrębne organizacje, którym nadawano potoczne nazwy, np. „POW”, "Partyzantka” itp.

O rozmiarach podziemia na północno-wschodnich ziemiach Polski, w tym i na Białostocczyźnie oraz o stanie jego rozpoznania świadczy informacja NKWD nr 1/4483, z 27 VII 1940 r. przekazana P. Ponomarence, z której wynika, że do tego czasu zdołano wykryć na północno-wschodnich ziemiach Polski 109 organizacji podziemnych wymienionych z nazwy, które skupiać miały według danych NKWD 3231 członków. 30 organizacji działało na Białostocczyźnie, skupiając 1190 konspiratorów ${ }^{4}$. Wykaz organizacji działających na Białostocczyźnie zawiera aneks 1, a dane statystyczne o ich składzie tabela 1 . Jak wynika $z$ tabeli 1 wśród członków wykrytych

3 Por. „Karta”, 1991, nr 5.

4 NARB w Mińsku, zesp. 4, spr. 21, t. 2078, k. 143-152. 
Tabela 1. Zestawienie statystyczne NKWD o wykrytych podziemnych organizacjach powstańczych działajacych w obwodzie białostockim w latach 1939-1940 (stan z 27 VII 1940 r.) ${ }^{5}$

\begin{tabular}{|l|c|c|}
\hline \multicolumn{1}{|c|}{ Wyszczególnienie } & $\begin{array}{c}\text { Ogółem } \\
\text { w organizacjach }\end{array}$ & $\begin{array}{c}\text { W tym w obwodzie } \\
\text { białostockim }\end{array}$ \\
\hline Liczba organizacji & 109 & 30 \\
\hline Liczba uczestników & 3231 & 1190 \\
\hline w tym: mężczyzn & 3011 & 1106 \\
kobiet & 220 & 84 \\
\hline Wiek & & \\
do 18 lat & 154 & 20 \\
18-25 lat & 1004 & 265 \\
powyżej 25 lat & 2273 & 905 \\
\hline Narodowość & & \\
Polacy & 2904 & 1141 \\
Białorusini & 184 & 14 \\
Żydzi & 8 & 4 \\
Litwini & 37 & 1 \\
pozostali & 98 & 30 \\
\hline Skład społeczny i zawodowy & & \\
obszarnicy i osadnicy & 278 & 58 \\
oficerowie & 244 & 83 \\
chłopi & 1164 & 479 \\
urzędnicy & 401 & 96 \\
kapitaliści i handlarze & 160 & 52 \\
młodzież szkolna & 439 & 973 \\
duchowieństwo & 14 & 9 \\
pozostali & 520 & 273 \\
\hline
\end{tabular}

Źródło: NARB w Mińsku, zesp. 4, spr. 21, t. 2078, k. 143-147, 152.

organizacji dominowali Polacy. Stanowili oni 92,5\% ogółu członków a na Białostocczyźnie - 95,8\%. Białorusinów było 5,7\% a na Białostocczyźnie tylko $1,2 \%$, natomiast Żydów zaledwie $0,2 \%$ a na Białostocczyźnie $0,3 \%$.

5 W dokumencie jest następująca uwaga: oprócz osób $\mathrm{z} \cdot$ wymienionych organizacji aresztowano 5584 osoby spośród byłych członków partii i organizacji (PPS, Bund, Stronnictwo Narodowe, POW i in.). 
Młodzież do 25 r. stanowiła $36,8 \%$ ogółu konspiratorów a na Białostocczyźnie $23,9 \%$.

Wśród 3231 członków wykrytych 109 organizacji podziemnych było w/g danych NKWD: obszarników i osadników $-8,6 \%$ a na Białostocczyźnie - 4,9\%, oficerów - 7,5\% a na Białostocczyźnie - 7\%, urzędników 12,4\% a na Białostocczyźnie $-8,1 \%$, kapitalistów i bogatych kupców $-4,6 \%$ a na Białostocczyźnie - 0,8\%. Najwięcej w konspiracji było chłopów - 36,0\% a na Białostocczyźnie $-41,6 \%$. Pozostali ( $w$ tym także nieokreśleni) stanowili $16,1 \%$ a na Białostocczyźnie aż $23,0 \%$. Kobiety stanowiły w podziemiu $6,8 \%$ konpirantów a na Białostocczyźnie 7,1\%.

Jeżeli chodzi o terytorialne rozmieszczenie to 30 organizacji działało na Białostocczyźnie, w tym $14 \mathrm{w}$ miastach: $5 \mathrm{w}$ Białymstoku, $3 \mathrm{w}$ Łomży, $2 \mathrm{w}$ Augustowie, $2 \mathrm{w}$ Wołkowysku i po $1 \mathrm{w}$ Grodnie i Sokółce. Pozostałe działały na terenach wiejskich, w tym $2 \mathrm{w}$ rejonie białostockim, $2 \mathrm{w}$ łapskim (wysokomazowieckim), $2 \mathrm{w}$ rejonie jedwabnieńskim, oraz po jednej w rejonach ciechanowieckim, lomżyńskim i zambrowskim. Miejsce działania pozostałych nie zostało bliżej określone.

Spośród wymienionych 109 organizacji tylko część stanowiły organizacje wojskowe lub ich ogniwa terenowe, głównie ZWZ prowadzące działalność zbrojną i dywersyjną w całości lub w grupach. Wedłyg danych NKWD z 28 XII 1940 r. zdołano na północno-wschodnich ziemiach Polski zlikwidować 28 takich grup zbrojnych, w których uczestniczyło 415 osób. Aresztowano też pod zarzutem współpracy z tymi grupami 230 osób. Podczas ich likwidacji zabito 42 osoby i 30 raniono. Zginęło też 4 pracowników NKWD i milicji oraz 7 osób odniosło rany. Odebrano wymienionym grupom dużą ilość broni, m.in. 15 CKM, 69 kb, 59 pistoletów, 87 granatów i ponad 27500 szt. amunicji ${ }^{6}$.

Grupy powyższe zanim zostały rozbite dokonały licznych akcji zbrojnych, w tym: 5 zamachów, w których zginęło 4 milicjantów i 2 raniono, zabito 1 oficera Armii Czerwonej i 1 zraniono. Zabito też 28 aktywistów i 2 raniono. Spalono 5 budynków w kołchozach? .

Znaczna część wymienionych działań miała miejsce na Białostocczyźnie. W maju 1949 r. przy Urzędzie Obwodowym NKWD w Białymstoku powołany został specjalny wydział do walki z „bandytyzmem”. Przy jego udziale udało się do grudnia 1940 r. zlikwidować 6 grup zbrojnych podziemia, are-

\footnotetext{
6 Tamże, t. 2081, k. 82-86.

7 Tamże.
} 
sztować j zlikwidować (zabić) w trakcie operacji 154 członków podziemia. Nadal jednak według danych NKWD z 8 XII 1940 r. w obwodzie białostockim działały 2 grupy zbrojne polskiego podziemia: $1 \mathrm{w}$ rejonie łapskim i $1 \mathrm{w}$ rejonie sokólskim ${ }^{8}$.

Część członków podziemia, zwłaszcza grup zbrojnych, pozostawała na stopie nielegalnej, inni zmuszeni zostali do ucieczki za granicę. Jak wynika z danych NKWD w dniu $15 \mathrm{~V} 1941 \mathrm{r}$. na nielegalnej stopie przebywało 860 konspiratorów, w tym $495(57,6 \%)$ na Białostocczyźnie. Za granice zbiegło 1111 osób, w tym 428 osób $(38,5 \%)$ z Białostocczyzny. Ich rodziny i krewni poddani zostali represjom i w większości deportowani na wschodnie obszary ZSRR ${ }^{9}$.

Szczególną aktywność według danych NKWD podziemie przejawiało na Augustowszczyźnie, w Łomżyńskim, zwłaszcza we wsiach nadbiebrzańskich oraz $\mathrm{w}$ powiecie sokólskim i dużych miastach, zwłaszcza w Białymstoku, Grodnie i w Łomży. Płk. P. Gładkow, naczelnik Zarządu Obwodowego NKWD w Białymstoku stwierdził w kwietniu 1940 r. na konferencji $\mathrm{KP}(\mathrm{b}) \mathrm{B}$, że w obwodzie białostockim istnieje duże zagrożenie ze strony polskiego podziemia. Mówił m.in.: „Wykryliśmy duże formacje w Białymstoku, Grodnie, Łomży, Augustowie, Sopoćkiniach. Otwarcie mówiono o wystąpieniach przeciwko władzy radzieckiej. Byli oni dobrze uzbrojeni w karabiny maszynowe, karabiny ręczne, mieli dużo amunicji, na przykład po 2-3, do 3,5 tysiąca sztuk amunicji na każdy karabin maszynowy. Widzimy więc, że te kontrrewolucyjne organizacje prowadzą walkę $z$ władzą radziecką i przygotowu ja przeciwko niej powstanie zbrojne" 10.

W innych dokumentach wymienia się aktywne ośrodki partyzanckie w Kobielnie nad Biebrza, w Puszczy Augustowskiej, w Puszczy Białowieskiej oraz w lasach grodzieńskich. Naczelnik NKWD rejonu augustowskiego na posiedzeniu RK KP(b)B w dniu 13 III 1940 r. przedstawiając sytuację w rejonie, stwierdził: „Sytuacja w rejonie charakteryzuje się sukcesami polskiej agentury. Udało się nam wprawdzie wykryć organizację powstańczą i rozbić jej sztab, pozostali jednak kontynuują działalność. Wrogi do nas stosunek wykazują uciekinierzy-handlowcy, aktywnie działają sekty, księża, przejawia się to w tym, że do kościołów obecnie uczęszcza 5-6 razy więcej osób niż było to dotąd. Burżuazyjno-nacjonalistyczne elementy przywód-

8 Tamże.

9 Tamże, t. 2431, k. 88-89.

10 Państwowe Archiwum Organizacji Społecznych Obwodu Grodzieńskiego (PAOSOG) w Grodnie, zesp. 6195, spr. 1, t. 38, k. 236. 
cze, otrząsnęły się po pierwszym uderzeniu RKKA i obecnie zdołały już odbudować kontakty itd." 11.

$\mathrm{Z}$ radzieckich dokumentów wynika też, że wbrew twierdzeniom władz, uczestnikami podziemia nie byli tylko oficerowie i osadnicy, których zresztą do wiosny 1940 r. zdołano już wyeliminować wraz z rodzinami. Na naradzie sekretarzy KR KP(b)B w Mińsku we wrześniu 1940 r. szef Rejonowego Oddziału NKWD w Augustowie przyznał, że „bandy mają swoje głęboko tkwiące korzenie wśród ludności i jej poparcie, dlatego tak trudno jest je zlikwidować". Przyznano też, że w organizacjach powstańczych jest sporo biedoty wiejskiej i średniego chłopstwa ${ }^{12}$.

Poparcie miejscowej ludności zmusiło NKWD do odstępstwa od stosowanych zasad i zastosowanie na Białostocczyźnie politycznych metod $w$ walce $z$ podziemiem. Zachęcano do dobrowolnego ujawniania się "gwarantując" bezpieczeństwo. Rzeczywiście przez pewien czas ujawnieni po złożeniu oświadczenia, że rezygnują $\mathrm{z}$ dalszej konspiracji, byli zwalniani do domów i pozostawieni czasowo w spokoju. Według danych NKWD w rej. jedwabnieńskim w okresie od 10 do 24 grudnia 1940 r. ujawniło się 86 członków ZWZ, w tym 2 komendantów palcówek, 6 komendantów drużyn i 78 szeregowych. Nie pozostawiono jednak ich w spokoju, jak zapowiadano. 19 spośród nich zwerbowano na agentów a pozostałych wciągnięto na listy do dalszego agenturalnego rozpracowania ${ }^{13}$. Wkrótce zostali oni wraz $\mathrm{z}$ rodzinami poddani represjom.

Zagrożenie ze strony polskiego podziemia zaniepokoiło miejscowe władze do tego stopnia, że 25 czerwca 1940 r. zwołane zostało specjalne posiedzenie Biura Komitetu Obwodowego KP(b)B w Białymstoku, na którym przy jęto uchwałę zobowiązującą służbę bezpieczeństwa i milicję do podjęcia dodatkowych przeciwdziałań a miejscowe komitety do okazania im wszechstronnej pomocy. Zalecono też wydawać czołowemu aktywowi broń oraz poinformować o sytuacji I sekretarza KC KP(b)B P. K. Ponomarenkę. Sekretarz $\mathrm{KO} \mathrm{KP}(\mathrm{b}) \mathrm{B}$ w Białymstoku S. Igajew wysłał alarmujący raport o stanie bezpieczeństwa w obwodzie białostockim, w którym poinformował, podając liczne przykłady, o aktywnej działalności podziemia ${ }^{14}$.

11 Tamże, zesp. 6197, spr. 1, t. 8, k. 13.

12 NARB w Mińsku, zesp. 4, spr. 21, t. 1922, k. 17 i 105.

13 Tamże, t. 2081, k. 217-218.

14 PAOSOG w Grodnie, zesp. 6195, spr. 1, t. 85, k. 178-180. Uchwałę Biura $\mathrm{KO} \mathrm{KP}(\mathrm{b}) \mathrm{B}$ w Białymstoku oraz raport S. Igajewa i uwagi P. Gładkowa autor opublikował w 1995 r. w „Studiach Łomżyńskich”, t. V, s. 156-159 i 163-164. 
Podjęte przez NKWD działania doprowadziły do rozbicia 10 VII 1940 r. sztabu PAW w Puszczy Augustowskiej. Dokonano aresztowań również na innych terenach. Podziemie jednak nadal działało, zwłaszcza na Augustowszczyźnie i w Łomżyńskim. W październiku 1940 r. do KC KP(b)B wpłynęła petycja od kierownictwa Zarządu Lasów w Augustowie, sformułowana w katastroficznych barwach, w której stwierdzono, że walka z poszczególnymi bojówkami „bandyckimi nie może dać efektów, że należy zwalczać nie pojedyncze osoby a całe wsie wspierające podziemie" 15 . Proponowano usunąć ze wsi wspierającą "bandytyzm” wszystką miejscową ludność i na jej miejsce sprowadzić Białorusinów, tylko wtedy - stwierdzają - rejon augustowski stanie się w pełni radzieckim i skończą się marzenia miejscowej ludności o Polsce i powrocie władzy polskiej ${ }^{16}$. Znacznie osłabione zostało też podziemie w rejonie jedwabnieńskim. Według danych NKWD do połowy września 1940 r. aresztowano w tym rejonie 245 osób, w tym za działalność konspiracyjną 205 osób. NKWD udało się 23 VI 1940 r. rozbić sztab partyzancki na Uroczysku Kobielno. Akcję starannie przygotowano pod kierownictwem zastępcy ministra spraw wewnętrznych Białorusi. Obok funkcjonariuszy NKWD do akcji zaangażowano pododdziały Armii Czerwonej. W czasie walk zginęło 9 partyzantów i 7 wzięto do niewoli. Do rąk NKWD trafiły dokumenty sztabu, w tym spisy 425 członków. Sztab mieścił się w 5 kamiennych bunkrach, dysponował dużymi zapasami żywnościowymi i niezbędnym sprzętem oraz transportem, m.in. 2 końmi i kilkoma rowerami. W jednej $\mathrm{z}$ informacji wymienia się nawet, że partyzanci mieli 3 samochody. NKWD oceniło, że sztabowi podlegały organizacje w okolicznych wsiach, skupiające do 1500 osób ${ }^{17}$.

$\mathrm{Z}$ radzieckich dokumentów wynika, że polskie podziemie niepodległościowe na omawianych terenach posiadało dużą ilość uzbrojenia. Według NKWD w okresie do $15 \mathrm{~V} 1941$ r. odebrano organizacjom podziemnym: 327 CKM, 45265 kb, 8617 pistoletów i rewolwerów, 6162 granaty i ponad 1770500 szt. amunicji. Dużo broni odebrano też podczas likwidacji sztabu partyzanckiego ZWZ w Kobielnie nad Biebrzą i sztabu PAW w Puszczy Augustowskiej (tabela 2). Wiele broni pozostawało nadal w rękach ludności i organizacji podziemnych. Według szacunków NKWD z 15 V 1941 r.

15 Autorzy petycji proponowali spacyfikować Stare Tajno, Brzozówkę i Bargłówkę i kilka innych wsi stanowiących siedlisko oporu.

16 PAOSOG w Grodnie, zesp. 6195, spr. 1, t. 91, k. 464-468.

17 NARB w Mińsku, zesp. 4, spr. 21, t. 2077, k. 323; spr. 5, t. 2199, k. 160-161. 
Tabela 2. Zestawienie statystyczne uzbrojenia przejętego przez NKWD od podziemia na północno-wschodnich ziemiach Polski (dane z 15 V 1941 r.)

\begin{tabular}{|l|r|}
\hline \multicolumn{1}{|c|}{ Rodzaje broni } & \multicolumn{1}{|c|}{ Ilość } \\
\hline Lekkie czołgi & 3 \\
Działa (różne) & 25 \\
Działa ppl. & 6 \\
Karabiny maszynowe & 327 \\
Karabiny ręczne różnych systemów & 42265 \\
Pistolety różnych systemów & 8617 \\
Rusznice ppanc. & 1 \\
Broń myśliwska & 152 \\
Granaty (różne) & 6162 \\
Bomby & 95 \\
Moździerze & 1 \\
Miny & 7 \\
Pociski do dział & 2194 \\
Rakietnice & 73 \\
Piroksylina (w tonach) & 14 \\
Dynamit (w tonach) & 76 \\
Dymne świece & 1200 \\
Kostki piroksylinowe & 64 \\
Pakunki piroksylinowe & 250 \\
Szable kawaleryjskie & 3370 \\
Spłonki do granatów & 110 \\
Zestawy do dywersji & 2 \\
Amunicja bojowa różnych systemów & 1770572 \\
Bagnety & 3147 \\
Taśmy z amunicją do karabinów maszynowych & 105 \\
Zamki do karabinów maszynowych & 3 \\
Lufy do karabinów maszynowych & 9 \\
\hline
\end{tabular}

Źródło: NARB w Mińsku, zesp. 4, spr. 21, t. 2431, k. 88-89.

podziemie dysponowało jeszcze m.in. 713 CKM, 485 kb, 537 pistoletami i rewolwerami, 10634 granatami oraz 355146 szt. amunicji ${ }^{18}$.

Zwraca się tė̇ uwagę w radzieckich dokumentach na dużą aktywność polskiego podziemia niepodległościowego, na wszechstronne przygotowania

18 Tamże, t. 2431, k. 88-89. 
do wystąpienia zbrojnego, na działania dywersyjne na liniach łączności oraz likwidację trapiących podziemie agentów NKWD (NKGB).

Reasumując należy stwierdzić, że radzieckie dokumenty stwarzają znaczne możliwości dalszych źródłowych badań dziejów polskiego podziemia niepodległościowego w rejonie białostockim w latach 1939-1941.

Radzieckie źródła, w tym również dokumenty NKWD (NKGB) odznaczają się, zarówno pod względem treści jak i formy, specyficznym charakterem. Dominuje w nich często retoryka nad treścią, a nierzadko fałszywe „naciągane" oceny i dyskryminu jące przeciwnika nazewnictwo. Np. polskie podziemie niep odległościowe zrównywane jest z „bandytyzmem”, a jego uczestnicy z bandytami. W jednej z odezw jest nawet określenie „generalska grupa bandycka".

Sporo jest też w radzieckich dokumentach, zwłaszcza dotyczących podziemia, nieścisłości w nazwach $\mathrm{i}$ w personaliach. Wynikają one zarówno z niedostatecznego rozpoznania polskiego podziemia, jak też ze stosowanej w podziemiu dezinformacji. Np. minister spraw wewnętrznych BSRR Ł. Canawa informował w raporcie nr 3/3/304 z 16 V 1940 r. P. Ponomarenkę, że sztabem podziemnym w Białymstoku kieruje gen. J. Olszyna-Wilczyński. Sztab w Białymstoku - według autora raportu - utrzymuje kontakty ze sztabem w Warszawie, którym kieruja generałowie F. Kleeberg i G. Orlicz-Dreszer. Wiadomo przecież, że gen. J. Olszyna-Wilczyński w tym czasie już nie żył, został rozstrzelany przez Armię Czerwoną 19 IX 1939 r. w drodze na Litwę, gen.F. Kleeberg przebywał w niemieckiej niewoli, gen. G. Orlicz-Dreszer we Francji.

Wiele trudności sprawia odtwarzanie na podstawie radzieckich źródeł obsady personalnej podziemia. Nazwiska osób aresztowanych podawane są najczęściej na podstawie nazwisk figurujących w dokumentach, którymi sie legitymowali. Np. płk A. Obtułowicz występuje jako Stefan Skubała. Dosyć często mylone są nazwiska w rozszy frowanych pseudonimach, np. prawdziwy pseudonim komendanta okręgu białostockiego ZWZ „Mścisław” rozszyf rowany został jako „Milewski”, a powinno być Liniarski.

Jednak uważna analiza dokumentów NKWD (NKGB) pomimo pomyłek i ich jednostronności, pozwala poznać bliżej nie tylko opinię NKWD (NKGB) o polskim podziemiu lecz także wzbogacić fotografię, ustalić rozmiar wpływów i rozmieszczenie siatki w terenie. Ważnym elementem dokumentacji są występujące często w dokumentach NKWD (NKGB) zestawienia statystyczne. Nie zawsze są to dane porównywalne, mogą té budzić wątpliwości co do wiarygodności części danych, stanowią jednak ważne konkretne świadectwo o podziemiu. Np. jest bardzo dużo danych 
statystycznych o odebranej podziemiu broni, o aresztowaniach i deportowanych.

Ważnym elementem części informacji NKWD (NKGB) o polskim podziemiu są załączniki w postaci dokumentów przejętych podczas aresztowania. Niestety w większości są to tylko uwiarygodnione tłumaczenia polskich dokumentów na język rosyjski. Materiał wyjściowy do sprawozdań oraz oryginały przejętych dokumentów są w archiwach NKGB Białorusi i nadal nie są udostępniane.

Dzięki radzieckim dokumentom można będzie ustalić nie tylko cele i mechanizmy działalności NKWD (NKGB) skierowanej przeciwko polskiemu podziemiu niepodległościowemu lecz także ich praktyczną realizację w terenie na szczeblu obwodów, miast i rejonów. Ustalić też można strukturę terenową radzieckich służb bezpieczeństwa oraz obsadę personalną, co pozwoli poznać nie tylko politykę władz radzieckich lecz też ludzi władzy.

Informacje $z$ dokumentów NKWD (NKGB) pozwalają także wyjaśnić różne kwestie personalne polskiego podziemia, np. okoliczności aresztowania i śmierci ppłk. A. Obtułowicza, podejrzanego o współpracę z NKWD oraz okoliczności aresztowania, ucieczki z rąk NKWD i śmierci A. Połubińskiego i wreszcie okoliczności wykrycia i rozbicia sztabu partyzanckiego ZWZ kpt. Burskiego na uroczysku Kobielno nad Biebrzą. Z dokumentów tych wynika także jaki był zakres i formy penetracji polskiego podziemia przez radzieckie służby bezpieczeństwa.

I na zakończenie pozostaje jeszcze wyjaśnić kilka kwestii związanych z nazewnictwem. Dla obszarów woj. białostockiego używam też zamiennie określenia „Białostocczyzna”, „Białostockie” lub „region białostocki”. Traktuję te ziemie jako okupowane obszary polskie, w latach 1939-1941 zajęte przez ZSRR, a następnie do lata $1944 \mathrm{r}$. przez Niemców. Ponieważ jednak władze radzieckie traktowały je jako ziemie, włączone w skład Białoruskiej SRR, występuje w dokumentach radzieckich podział administracyjny, wprowadzony tu w końcu 1939 r. t.j. podział na obwody (szczebel wojewódzki) i rejony (szczebel powiatowy).

Wyjaśnienia wymaga też występujące w dokumentach różne nazewnictwo radzieckich służb specjalnych, zajmujących się zwalczaniem polskich dążeń niepodległościowych na omawianym terenie. Do kwietnia 1941 r. radzieckie służby bezpieczeństwa państwowego wchodziły w skład resortu spraw wewnętrznych (NKWD), a następnie zostały wydzielone w odrębny resort funkcjonujący równolegle z NKWD. Dla omawianego okresu używano ogólnego określenia „NKWD”. Pamiętać też należy, że zwalczaniem polskiego podziemia i innych form oporu zajmowały się na omawianych tere- 
nach również powstałe struktury władz radzieckich, a więc także komitety $\mathrm{KP}(\mathrm{b})$ i komitety wykonawcze rad delegatów ludu pracu jącego. Główny jednak wysiłek w walce $z$ podziemiem spoczywał na służbach bezpieczeństwa (KGB) niezależnie od tego czy wchodziły one w skład NKWD czy były odrębnym resortem. Sprawozdanie tych służb i informacje o polskim podziemiu stanowią więc ważne źródło do badań nad omawianym tematem.

Przekazujemy do rąk czytelnika wybór 20 dokumetów i 2 materiały $\mathrm{w}$ aneksie. Dokumenty publikujemy w oryginale, tj. w języku rosyjskim. Natomiast aneks 1 zawiera niedostępne w oryginale tłumaczenie polskiego dokumentu na język rosy jski przez tłumacza NKWD. Aneks 2 zawiera krótkie informacje o wykrytych organizacjach ujęte w skrócie w polskim tłumaczeniu na podstawie obszernego dokumentu NKWD. Nazwy organizacji przetłumaczone zostały dosłownie. 


\section{Dokument 1}

1940 maj 5, Mińsk, - Raport ministra spraw wewnętrznych BSRR o wykryciu podziemnej organizacji w obwodzie biatostockim.

COBEPШEHHO CEKPETHO $^{a}$ СЕКРЕТАРЮ ЦК КП(б) БЕЈОРУССИИ товарищу ПОНОМАРЕНКО

$\mathrm{UK} / 4$

Минск

\section{ДОКЈА ДНАЯ ЗАПИСКА}

На территории Ломэкинского, Замбровского и Чижевского районов Белостокской области вскрыт и частично ликви,дирован филиал контр-революционной, польской повстанческой организации.

Сигналюм о существовании филиала контр-революционной повстанческой организации в выше перечисленных районах послужили данные, полученные следствием по делу арестованной за контр-революционную деятельность жительницы города Белостока ЈIИСОВОЙ Марии о том, что в монастыре г. Ломжи имеется спрятанное оруже и она - ЈІИСОВАЯ цолжна была выехать в горо,ц Јомжу, св.язаться с монахами по паролю „Я от Польмин” и получить у них оружие.

Дляя проверки показаний ЈИСОВОЙ Марии был послан в гор. Ломжу маріпрутный агент „ВОЛІОДИН” с задачей свясаться с монахами, при помоци указанного пароля, установить наличие в монастыре оружия.

В результате проведенной агентурной комбинации, агент „ВОлІДИН" установил связь с монахом и получил от него адрес переправпцика ПОДБЕЛЬСКОГО Александра, проживающего в дер. Подбелье, Снядовского района, который занимается переброской контр-реболюционного элемента в Германию. Для св.язи с ПОДБЕЛЬСКИМ монах „ВОЛІОДИНУ” дал пароль - „Я от Сусла” (кличка скрывающегося польского офицера-руководитель филиала контр-революционной повстанческой организации) ${ }^{1}$. В отнопении оружия монах „ВОЛІО ДИНУ” заявил:

„Я делюм не ведаю, учетом, распределением оружия занимается центр, он имеет паспорта о состоянии организации и наличии оружи.я". 
.Дальнейшей работой с агентом „БОЛОДИНЫМ” была усановлена связь с переправщиком ІІО.ДБЕЛЬСКИМ Алексан,дром, который нашему агенту „БОЛО.ДИНУ” сообщил, что им были нелегально переброшены на территорию Германии три бывпих польских офицера: ВРУБЛЕВСКИЙ, СУІЦИН и ЗМЕНТОВСКИЙ. Кроме того, дал адреса „ВОЛОДИНУ”: БОЧЕВСКОГО, проживаюшего в дер. Врубля и ВИІІНЕВСКОГО Яна, проживающего в дер. Родвань, через которых „ВОЛОДИН” сможет установить связь с руководителем филиала контр-революционной, повстанческой организации бывпиим польским офицерам "СУСJI" по паролю „ВОЛЬНОСТЬ".

О наличии контр-революционной, повстанческой группы в дер. По.цбелье и оружия повстанцев, ІІОДБЕЈЬСКИЙ агенту „ВОЛОДИНУ" заявил:

„В нашем кружке в дер. Подбелье состоит 10 человек, из них поэовина по,дофицеров. Имеется 40 винтовак, один ручной, о.дин станковский пулемет и много патрон".

Продолжая посылку в маршруту агента „ВОЛО.ДИНА” были дололнительно установлены участники контр-революционной, повстанческой организации - НЕМИРО Антон, МЫСЈИНСКИЙ Юзәф, ГЈАМБОВСКИЙ Мечислав и БОЧЕВСКИЙ Мечислав.

В целях ликви,дации контр-революционной деятельности филиала повстанческой организации, выявлены все участники и изъятия имеюшегося в организации оружия, по,цвергнуты аресту следующие:

1. ІІО.ДБЕльСКИЙ Алексан,др Марцелевич.

2. ГЈЕМБОВСКИЙ Мечислав Якубович.

3. ГЈЕМБОВСКИЙ Казимир Томашевич.

4. БОЧЕВСКИЙ Мечислав Јаврентьевич.

5. СИКОРА Франк Иванович.

6. МЫСЈИННКИЙ Юзоф Алексан,црович.

7. ІІО.ДБЕЛЬСКИЙ Франтипек.

8. НЕМИРО Антон Константинович.

9. ВИІІНЕВСКИЙ Ян Юзефович.

10. ВИІІНЕВСКАЯ София.

11. МОНЬКО Генрих Антонович.

12. ІІОДБЕЛЬСКИЙ Ян Марцелевич.

13. МАРКОВСКИЙ Ян Марцелевич.

14. ИМИЛИТ Франтипек Феликсович.

15. MEX Алексан,др Станиславович. 
16. ЛЕЩИНСКИЙ Юзэф Станиславович.

Следствием по делу выпе перечисленных участников филиала контр-революционной, повстанчецкой организации установлено наличие склада оружия в организации, которое хранится в специально приготовленных в земле ямах - в 200 метрах от хутора гр-на КУНКОВСКОГО Станислава в Снядовском районе.

Выез,дом на место оперативной группы были обнаружены две ямы, из которых из'ьято сле.дуюшее оружие и боеприпасы:

1. Станковый пулемет № 1375 с двумя запасными замками.

2. Ручной пулемет № 4519.

3. Четыре запгасных ствола к пулемету.

4. Коробка с запасными частями к станковому пулемету.

5. Пламягаситель к ручному пулемету.

6. Три заряженных гранат и одун запасной капсул.

7. Два,дцать польских винтовак.

8. 14 пітыков к винтовкам.

9. 4 польских каски.

10. 18 польских противагазов в сумках.

11. Три польских противогаза без сумок.

12. 16 пулеметных эент в коробках с 3700 пाтук патронов.

13. 20 подсумков с 900 патронами.

14. Ящики с винтовочными патронами - 1211 пाтук.

15. Магазины к ручному пулемету с 280 патронами.

(О выпе перечисленном из'ьятым оружию мною было доложено Вам телеграммой № 1/1440 от 24 марта 1940 года). ${ }^{b}$

Кроме того , из'ьят личное оруже, находивпееся у следующих участников филиала повстанческой организации:

1. ПОДБЕЛЬСКОГО А. М. - винтовка и 245 патрон.

2. ПОДБЕЛЬСКОГО Д. Я. - винтовка.

3. НЕМИРО А. К. - винтовка и 190 патрон.

4. ВИШНЕВСКОГО Д. - винтовка и 55 патрон.

Следствием установлено, что филиал польской контр-революционной, повстанческой организации был создан в сентябре мес. 1939 го,да поручником польской армии СУСЛО, он же МАРЕПКИЙ - МАЗЕЦКИЙ - СКОВРОНЕК Антоном ${ }^{2}$. Последний, с разгромом частей польской армии и с занятием Белостокской Области частями Краснои Армии, перепел на нелегальное положение и приступил к созданию контр-революционных, повстанческих групп (СУСЛО в ,данное время скрывается). 
Филиал повстанческой организации строился по принцигу плтерок и комендатур, умели свои переправочные пункты для переброски руководящего состава организации и курьеров за границу и обратно. Кроме того, организация имела связь с нелегально сушествовавшим пгтабом в Варшаве.

Арестованный комендант филиалга повстанческой организации ПОДБЕЈЬСКИЙ Александр Марцелевич показал:

„Іовстанческая организация, участником которой являюсь я, руководилась, как это мне узвестно со слов СУСЛО, подпольным пгтабом организации, находившимся в гор. Варшаве".

„Со слов того-ж СУСЛО, мне известно, что на территории Германии и СССР существует болыная польская организация, которой охвачены все деревни бывпего Варшавсйого воеводства и многие деревни, находвпееся на территории запаных областей БССР и Украины. Кроме Варшавского штаба, сушествуют шітабы повстанческой организации в г. Лвове, Белостоке, Гродно и Вильно",

Кроме связи с Варпавским штабом филиал контр-революционной повстанческой организации подлерживал связь со пітабом повстанческой организации во Јьвове, обвиняемый ІІОДБЕЛЬСКИЙ по данному вопросу показывает:

„В январе мес. 1940 года из г. Јьвова приезжала курьерша повстанческой организации некая Эмилия, совместно с капитаном бывшей польской армии, по фамилии как будто Морозовским ${ }^{3}$, последний приезжал на связь к СУСЛО, в последствии капитан МОРОЗОВСКИЙ был переброшен за границу".

Следствием также установлено, что кроме поручика Сусло у руковоцства филиалом польской повстанческой организации стоит поручик бывпего 71 замбровского полка бывшей польской армии ПJЕВО Станислав, последний в данное время скрывается.

Кроме того, участниками организации являются Монахи монастыря гор. Ломжа.

1. ГАII Петер Иванович, 1907 года пождения, является руководителем монастыря.

2. ІІОМБРОВСКИЙ Генрик Антонович, 1910 года рождения, монах, является сыном арестованного руководителя контр-революционной организации ЛОМБРОВСКОГО Антона.

Следствие продолжается в направлении выявления всех участников повстанческой организации, оружия и их связей со Львовом, Белостоком и Гродно. Одновременно приняты меры к розыску и аресту 
руководителей филиала контр-революционной, повстанческой организации офицеров бывшей польской армии СУСJО и ПЈЕ ЕВО.

В целях пересечения контр-революционной, повстанческой деятельноцти, проводимой монахами Јомжинского монастыря подергнуть аресту руководителя монастыря ГАІІ Петра Ивановича и монаха ДОМБРОВСКОГО Генрика Антоновикіа.

\section{НАРОДНЫЙ КОМИССАР ВНУТРЕННИХ ДЕЈ

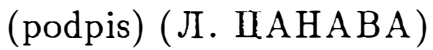

5с мая, 1940 года

№ $2 / 2170$

гор. Минск - БССР

Oryginał, maszynopis.

Źródło: NARB w Mińsku, zesp. 4, spr. 21, t. 2077, k. 30-36.

a Wielkie litery oryginału.

b Tekstu telegramu autor nie odnalazł.

c Dzień wpisany odręcznie.

1 Prawdopodobnie chodzi o por. Antoniego Iglewskiego.

2 Pomyłka. Iglewski nie używał nazwiska Skowronek. Jest to nazwisko komendanta obwodu łomżyńskiego ZWZ por. Franciszka Skowronka, ps. „Jackowski”.

3 O „Emilii" i kpt. Morozowskim brak danych. 


\section{Dokument 2}

1940 czerwiec 23, Mińsk, - Pilny meldunek ministra spraw wewnętrznych BSRR o zlokalizowaniu $w$ lasach rejonu mońkowskiego $i$ jedwabnowskiego zbrojnej grupy polskiego podziemia $i$ skierowaniu $w$ celu jej likwidacji grupy operacyjnej na czele z zastępca ministra.

СОВЕРШЕНHО CEKРETHO

СЕКРЕТАРЮ ШК КП(б) БЕЛОРУССИИ товарищу ПОНОМАРЕНКО

г. Минск

\section{СРОЧНОЕ ДОНЕСЕНИЕ}

По агентурным данным, стало известно, что в лесах Моньковского и Едвабновского пайонов, Белостокской области, скрывается банда в количестве несколько десятков человек и состоит из бывпих офицеров польской армии, полицейских и других, которые с первых же дней советизации в Западной Белоруссии, перепли на нелегальнове положение.

Проведенным агентурным мероприятием один из участников банды - СТЕФАНИН Бронислав Апполинарович, оставил банду и с оружем сдался нам, через которого установлено - часть состава банды известна СТЕФАНИНУ, месторасположение, численный состав и вооружение банды.

По его же показаниям установлено также, что банда не имеет регулярхого состава за исключением руководства банды, а она пополяется в ночное время за счёт скрываюшихся из-за боязни репрессий за свою проплую антисоветскую деятельность, жителей указанных районов, которые в дхевное время возвращаются в свои же села.

В результате дополнительных мероприятий, 22 июня 1940 года нашей засадой захвачено жживыми ещё 3 участника банды - BEСЕЛОВСКИЙ Станислав Станиславович, МЕТИЕВСКИЙ Вацлав Янович и ДОМБРОВСКИЙ Генрик Францевич, которые подтвердили свое участие в банде и показали, что в числе других вооружений банда располагает большим количеством станковых и ручных пулеметов .

На основании этих материалов, для ликидации банды на место 
выброшена оперативная группа во главе с моџм заместителем тов. ДУХОВИЧЕМ, с достаточным количеством командиров, бойцов наIIIих войск и частей PККА.

Результаты операции донесу.

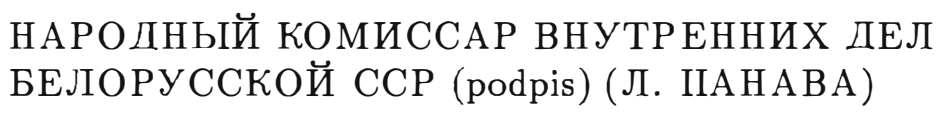

№ $2 / 3101$

$23 / \mathrm{VI}-40$ г. $^{\mathrm{b}}$

$\mathrm{Na}$ górze $\mathrm{z}$ lewej strony $\mathrm{w}$ prostokątnej pieczątce wpisany nr wpł. 1459 (odręcznie) i data 23 czerw. 1940 r.

Oryginał, maszynopis.

Źródło: NARB w Mińsku, zesp. 4, spr. 21, t. 2077, k. 319-320.

a Wielkie litery i podkreślenia oryginału.

b Numer i data wpisane odręcznie.

\section{Dokument 3}

1940 czerwiec 24, Mińsk, - Pilny meldunek ministra spraw wewnętrznych BSRR w sprawie rozbicia sztabu organizacji powstańczej w uroczysku Kobielno nad Biebrza.

COBEPIIIEHHO CEKPETHO ${ }^{a}$

СЕКРЕТАРЮ ЦК КІІ(б) БЕЈІОРУ ССИИ товарищу IIOHOMAPEHKO г. М И Н C K

\section{СРОЧНОЕ ДОНЕСЕНИЕ}

В дополнение к моему донесению за № 2/3101 от 23/VI-40 г. ${ }^{1}$ доношу: Показаниям арестованных бандитов - ВЕСЕЈОВСКОГО, МЕТИЕВСКОГО и ДОМБРОВСКОГО, а также агентурой было 
установлено точное место нахождения штаба руководства, на стыке Ещвабновского и Моньковского райнов, Белостокской области, в местности урочище Кобельное, в густом лесу окруженном болотами.

По заранее разработанному нами плану проведения операции по ликвидации банды, в эту местность была выброшена оператувная группа работников НКВ.Д с бойцами наших войск и пулеметного батальона РККА.

23 июля, в 8 часов утра оперативная группа окужила место расположения бан $\mathrm{I}^{2}$. В завязавшейся перестрелке между нашей группой и бандитами полностью разгромлен пітаб руководства банды: убито 9 человек и взято живыми 7 человек.

Захвачены живыми -

1. ХМОДИНСКИЙ Яаков Брониславович, бывний подпоручик польской армии, заместитель комен.данта пштаба банд.

2. ХАЛИНСКИЙ А.дам Антонович, связист банды с повстанческими организациами.

3. КУРКУС Казимир Станиславович, капрал бывшей польской армии, быв. начальник Едвабновской районной почты, перешол на нелегальное положение в мае месяце.

4. ПАРОВСКИИ Болеслав Иванович, недавно вернувшийся из Литвы, как интернированный при отступлении польских войск.

5. ПЕДЖИПКИЙ Антон Викентьевич, из крестьян, активный член повстанческой организации, в апреле месяце перешедший на нелегальное положение.

6. ЗАМЕШКИЙ Косиф Никодемович, нелегально прибывпий из Остроленко (Германия), в банде выполнял обязанности связиста.

7. ХЈАВИНСКАЯ ЮОлия Станиславовна, недавно прибывшая из Варшавы нелегально.

В числе убитых установлены и опознаны:

1. МИЦКЕВИЧ А.дам, бывпий поцпоручик польской армии, член пाтаба вскрытой нами в апреле м-це подпольной Белостокской организации, после ликвидации организации перешел на нелегальное положение, в банде выполнял обязанности первого заместителя коменданта банды.

2. УСЕЩКИЙ Генрик, подпољьная кличка „БУДРИС”, подхоружий бывшей польской армии, в бан.де выполнял обязанности заместителя коменданта пітба банд.

3. ОДИНЕЦ Антон, подпольная кличка „ГРОМ”, старший сержант бывпей польской армии. 
4. ПШИБИЛЯХ (имя и отчество пока не установлены)

5. ЛЕУДИНСКАЯ Ядвига, недавно прибывпая нелегально из Варшіавы, член повстанческой организации.

6. ВОЙСЛАВОВИЧ (имя и отчество не установлены), подлежащая репрессии, как жена лесника, находяегося на нелегальном положении.

Личности остальных трех убитых устанавливаем. С нашей стороны никаких жертв не было.

У ликвидированного пाтаба банды из'ьято:

1. Станковий пулемет, польский - 1, с 4-мя лентами патрон к нему.

2. 9 польских карабинов и 2000 патрон к нум.

3. 6 револьверов системы „Броунинг”.

4. 11 польских гранат.

5. 8 кинжалов.

6. Полевой телефонный аппарат.

7. Радио-приемник с аккумулятором.

8. 2 ящика с медикаментами.

9. 1 больпой ящик с аптечками.

10. Фото-аппарат „Лейка".

11. 2 военных пиинели, 1 фирмы войск НКВД, вторая общеармейская. Эти пинели бандой использовывались для соверения террористических актов.

Банда была располюжена в лесу в двух выстроенных шалапгах. Располагали достаточным количестом продуктов питания. В одном из ппалашй был расположен пштаб руководства, где нами из'ьято документы и другая щереписка банды. В числе документов найболее характерными являғотся:

1. Список членов организации на 79 человек, датированный 25 мая 1940 года, с указанием фамилии, имени, отчества и клички указанных членов повстанческой организации.

2. 22 конверта, заготовленных на имя коменцантов пляцувок, с указанием фамилии, имени и отчества комендантов пляцувок, деревни и старшего руководителя повстанческой организации по деревне.

3. Приказы на имя комендантов пляцувок и по несколько пाтук приказов на имя членов организации, вхоцяцих в ведение этой пляцувки.

Содержание приказа на имя коменданта пляцувки следуюгцие: 


\section{„Приказ - выступление"}

„Напге время настало, идём в бой с врагом. Все мы добровольно идём в бой. Приложенные при этом приказы солдатам, вручить им и проверить на месте все ли получили приказы.

Пляцувка забирает с собой:

1. Имеюгциеся оружие и боеприаасы.

2. Заготовленные продукты.

Коменданту пляцувки по,д јичную ответственность за точное и своевременное выполнение приказа.

Районный комендант отдела."

Приказ дляя членов организации:

„Приказ боевой для выступления"

"Старігему члену немедленно явиться на место сбора, зарегистрироваться у старігего своей дружины, вручив ему этот приказ, забрать с собой продукты на одни сутки."

Далыне в тексте идёт название части, обозначённые пунктирами для заполнения, тоже самое компании, и тоже самое место сбора.

4. 40 пाтук возваний повстанческого характера, разного содержания.

5. Книга учёта членов организации, которая заведена недавно и записано только 24 челювека.

6. Тетради с разработанными темами строевых и тактических заниятий.

7. Печатный шттамп пітаба руководства.

8. Резиновый пюрифт на польском языке для набора и друга.я переписка.

Арестованные участники банды доставлены в Едвабновское РО. На предварительном допросе сознались. Сегодня под конвоем переводятся для разворота следствия в гор. Белосток, Областное Управление.

Трупы убитых бан,цитов сего,дня ночью будут доставлены в районный центр, для установления личности неопознанных, после чего закопаны.

Намеченные оперативные мероприятия, для выявления и ареста всех участников банды и повстанческой организачии.

О результатах донесу.

НАРКОМ ВНУТРЕННИХ ДЕЛ БЕЛОРУССКОЙ ССР КОМИССАР ГОСБЕЗОНАСНОСТИ 3 РАНГА (Л. ЦАНАВА) 
"24"ь июня 1940 г.

№ $2 / 3102$

гор. Минск

Na górze z lewej strony w prostokątnej pieczątce wpisano „Wpł. 1461, 25 czerw. 1940 r." i niżej ukosem adnotacja Ponomarenki czerwonym atramentem „Dobrze", podkreślone i podpis.

Oryginal, maszynopis.

Źródło: NARB w Mińsku, zesp. 4, spr. 21, t. 2077, k. 323-329.

a Wielkie litery i podkreślenia oryginału.

b Dzień miesiąca wpisany odręcznie.

1 Por. dok. 2.

2 Chodzi o uroczysko Kobielno nad Biebrza.

\section{Dokument 4}

1940 lipiec 17, Minss, - Informacja specjalna ministra spraw wewnętrznych BSRR o dodatkowych aresztowaniach wśród członków $Z W Z w$ okręgu biatostockim.

$3 \pi / 4$

COBEP ШЕHHO CEKPETHO $^{a}$

\section{СЕКРЕТАРЮ ШК КШ(б) БЕЈОРУССИИ товарищу ПОНОМАРЕHКО \\ г. Минск}

\section{СПЕПСООБЩЕНИЕ}

В дополнениу к № $1 / 3434$ от 17.V.-40 г. ${ }^{1}$ по вскрытой и ликвидированной контреволюционной, повстанческой организации „Союз вооруженной борьбы", дополнительно выявлено и арестовано 12 человек, а всего по делу арестовано 18 участников, из них быв. офицеров и полицейских 7 , кулаков 6 и прочих 5 .

За этот период разоблачено 10 -участников, которые подтвердили о наличии к/р организации "Союзы вооруженной борьбы" и свою прина,цлещность к организации. 
Следствием установлено, что руководитель Белостокской уез,дной к/р организации "СВБ” - капитан б. польской армии ДЯНКЕВИЧ ${ }^{2}$ (разыскивается), назначил комендантом филиала организации "СВБ” в м. Хорощ подпоручик быв. польской армии ГЖЕНДЕЛЬСКОГО Ю. В. (арестован), а на случай провала организации и ареста ГЖЕНДЕЛЬСКОГО комен,дантом этой организации был назначен капрал быв. польской армии МАРКОВСКИЙ Генрик (арестован, призналгя).

В ноябре-декабре м-це 1939 го.да пре.дставитель Белостокской уез.дной организации ЖАРСКИЙ-ШМИДТ принимал у себя на квартире г. Белюсток, ул. Огродовая 13, зам. комен.данта филиала к/р организации „СВБ” г. Хорощ - МАРКОВСКОГО Генрика и пере.дал ему инструкции по работе.

В первых цислах января м-ца 1940 го,да комен,цант „СВБ” м. Хопрщ, ГЖЕНДЕЛЬСКИЙ находясь в гор. Львове у своих ро,цителей имел встречу со своей знакомой участницей к/р организации медсестрой СМАЛЬНИЩКОЙ Еленой (арестована) и с ее по-


вор о к/р деятельности повстанческой организации, суцвствовавшей в гор. Јьвове.

В одной из бесед „Бернар.д” сообщал ГЖЕНДЕЛЬСКОМУ, что в Јьвовской к/р организации имелся самолет „Карась” - оставлен быв. польской армией: на котором в декабре м-це 1939 года перелетели в Румынию 7-м летчиков и механиков - участников к/р повстанческой организации.

Участники антисоветского по,цполья неоднократно собирались на нелегальное сборище. На 2-х таких нелегальных сборищах присудствовал КРАУЗЕ, быв. лесник, до ареста проживал на нелегальном положении, являлля о.дним из активных участников к/p организации.

На проведенных нелегальных сборищях ДЯНКЕВИЧ, известен в организации под кличкой „Фред”, давал задания консультантам низовых организаций, выявлять и собирать оружие, а также распиирять состав участников организации за счет вовлечения новых членов.

Следствие по данному делу направляем на выявление новых участников контреволюционной повстанческой организации „Союз вооруженной борьбы", ее руководящего центра, установления и из'ьатия оружиа.

Активизируем агентурно-оперативное мероприятие по розыску 
и задержанию участников повстанческой организации, проживающих на нелегальном полозкении, в том числе руководителя „СВБ” ДЯНКЕВИЧА и активных участников к/р повстанческой организации ЖЕНДЗЯНА Петра и КУЈІИКОВСКОГО Чеслава.

О результатах следствиа сообщу дополнительно.

НАІІДНЫЙ КОМИССАР ВНУТРЕННИХ ДЕЈ БССР (podpis) (JI. IIAHABA)

"17 ь июоляя 1940 года

№ $1 / 4104$

Минск

Na górze dokumentu adnotacja: „KC KP(b)B, wpł. nr 1673, 18 lip. 1940”. Oryginal, maszynopis.

Źródło: NARB w Mińsku, zesp. 4, spr. 21, t. 2078, k. 42-45.

a Wielkie litery i podkreślenia oryginału.

b Dzień wpisany odręcznie.

1 Autor wymienionego raportu nie odnalazł.

2 Nazwisko kpt. Diankiewicza nie występuje w polskich dokumentach.

3 Pseudonim nierozszyfrowany.

\section{Dokument 5}

1940 sierpień 16, Mińsk, - Informacja specjalna ministra spraw wewnętrznych BSRR o wykryciu sktadu broni ZWZ w okolicy Jedwabnego i ukrywającym się dowódcy tej organizacji kpt. A. Burskim.

$\ni \Gamma / 4$

COBEPIEHHO CEKPETHO $^{a}$

СЕКРЕТАРЮ IК КІІ(б) БЕЈІОРУССИИ товарищу ПОНОМАРЕНКО

C II E I - C O O B IE E U E

В дополнение к № 2/3101, от 23/6 - 1940 го.да ${ }^{1}$ докла,дываю: 
По Іоказаниям арестванного члена контр-революционной повстанческой организации, коменданта пляцувки дер. Хилины, Едвабновского района Белостокской области - КАРВОВСКОГО Франца Яновича, 1917 го,да рождения, дополнительно вскрыт скла,д оружия штаба повстанческой организации, руково,димого БУРСКИМ - „ШШУЈЯКО М”.

Скла,ц нахо,цился в земле в 5 метрах от сарая лесника ВОЙСЈАВОВИЧА, по.ц кучами хвороста. В яме обнаружено и из'ьято:

1. Винтовок разных

$-5$

2. Обрезов

$-3$

3. Револьверов разных

$-6$

4. Шашек

$-7$

5. Пулеметных стволов

$-4$

6. Зенитных установок для пулемета -1

7. Магазинов ,цля пулемета

$-19$

8. Пулеметных лент

$-4$

9. Ручных гранат

$-2$

10. Винтовочных патрон

$-11106$

11. Военное имуцество

- 33 разных наменований.

КАРВОВСКИЙ также показал, что член пाтаба повстанческой организации - ВОЙСЈАВОВИЧ, после побега в момент операции в Едвабновском районе, заходил к КАРВОВСКОМУ и рассказал ему о происше,цшем разгроме пाтаба организации, взял у него сапоги и скрылся.

Через три дня к КАРВОВСКОМУ явился комендант повстанческой организации БУРСКИЙ - ІШУЈІЯК у которого скрывался несколько дней.

По агентурным данным БЫРСКИЙ - „ІШУЈІЯК” скрывается в деревне Колоная.

С целю маскировки БУРСКИЙ прекрасил себе волосы в черный цвет, отрастил усы, искусственно сделал арминат носа.

Приняты меры к установке и поимке БУРСКОГО.

НАРО.ДНЫЙ КОМИССАР ВНУТРЕННИХ ДЕЛ БЕЛОРУССКОЙ ССР (podpis) (JI. IIAHABA)b

"16"с августа 1940 г.

№ $2 / 5362$

г. Минск 
Oryginał, maszynopis.

Źródło: NARB w Mińsku, zesp. 4, spr. 21, t. 2078, k. 231-232.

a Wielkie litery i podkreślenia oryginału.

b Słowo „Canawa” przekreślone, dopisano „Zast.”. Podpis nieczytelny.

c Dzień wpisany odręcznie.

1 Por. dok. 2.

\section{Dokument 6}

1940 sierpień 26, Mińsk, - Raport ministra spraw wewnętrznych BSRR o wynikach agenturalnej działalności stużb specjalnych skierowanej przeciwko polskiemu podziemiu w Szczuczynie i okolicznych wsiach.

$3 \Pi / 4$

COBEP ШEHHO CEKPETHO $^{a}$

СЕКРЕТАРЮ ШК КП(б) БЕЛОРУССИИ товарищу ПОНОМАРЕНКО (Лично) М И Н C K

ДО К Л А Д Н А Я 3 А ПИ СК А

По агентурно-следственному делу „ПИЛСУДЧИКИ”

В мае месяце 1940 года заведена агентурная разработка „ПИЛСУДЧИКИ", на группу повстанцев, проводивших антисоветскую повстанческую деятельность на территории г. Шучино, дер. Свириды, Жебры, Вонсош и других Белостокской области.

Арестованный в конце июля сего года фигурант разработки КОНОПКО Болеслав Брониславович на следствии рассказал, что является комендантом контрреволюционной повстанческой организации д. Свириды, одновременно назвал ряд комендантов и участников повстанческой организации в г. Шучие и других селгах Граевского раиона, Белюстокской области.

Кроме того КОНОПКО показал, что организация своей деятельностью охватывает территопию бывшего Шучинского уезда и что штаб ее находится в дер. Рутки около гор. Ломжа во главе 
с офицеров бывпеей польской армии по кличке „СУСЛО”. Для руково.дства организацией на место, в мае 1940 го,ца, приезжал офицер „СТАНИСЛАВ"1, который в конце июня сего года в м. Радзилове, Едвабновского района был убит милиционером при попытке за,держания его.

После убийства „СТАНИСЛАВА”, на его место приехал офицер "СТЕФАН" брах, занимался организацией повстанческой деятельности в населенных пунктах Граевского, Кольновского районов.

При ликвидации организации арестовано 10 человек комендантов пляцувок повстанческой организации и их заместителей. Болыпинство из арестованных на следствии признались, назвали свыне 50 человек членов организации и рассказали о практической деятельности после,цней.

Кроме того в процессе следствия было установлено наличие у организации диверсионного магазина, спрятанного на уса,цьбе быв. наро,довца ДОМБРОВСКОГО Юзефа (арестован в октябре 1939 го,ца) около г. Шучино.

Принятыми агентурно-оперативными мероприятиями 15 августа сего го,да, на картофельном поле ДОМБРОВСКОГО Юзефа, в 2 клм. от г. Шучино указанный диверсионный магазин был обнаружен и из'ьят, в котором при вскритии оказалось:

1. 4 по.дрывных шапюки по 1 кг. каждая.

2. 4 подрывных шашки по 500 грамм каждая.

3. 4 гранаты „Мильса".

4. 4 детонатора к гранатам "Мильса".

5. 4 химических зажигателя с капсюлями для поддрывных заря,цов.

6. 1 термический по,дрывной 100 граммовый заря,Д, для подрывания котлов.

7. 10 пाтук капсюлей-детонаторов ,для по,дрывных шашек.

8. 3 пштуки электродетонаторов с капсюлями.

9. 5 метров наружного бикфор,дового шнура.

10. 1 метр подво,дного бикфор,дового пшнура.

11. 1 клубок изоляционной ленты.

12. 1 перочинный ножичек.

Все это было герметически закупорено в жестяных запаянных банках.

По даному делу арестованы следуюлцие лица: 
1. ГАЗОВСКИЙ Чеслав, 1909 года пождения, капрал бывпей польской армии, комендант повстанческой организации в д. Жебрах, Граевского района, проживал там-же.

2. НАГУРСКИЙ Болеслав Юзефович, 1919 года рождения, плютоновый бывпгей польской армии, комендант повстанческой организации в г. Щучино, Граевского района, проживал там же.

3. ЯНКОВСКИЙ Ян Александрович, 1910 года рождения, капрал быв. польской армии, комендант друљкины и заместитель коменданта повстанческой организации д. Жебры, Граевского района, проживает там же.

4. ПЕХОТИНСКИЙ Витольд Александрович, 1913 года рождения, ст. пाереговый бывпей польской армии, комендант д. Кендзерово, Граевского района, проживает там же.

5. ЮШКОВСКИЙ Чеслав Станиславович, 1913 года рождения, ст. шереговый бывпей польской армии, быв. „народовец”, заместитель комен,данта повстанческой организации д. Вонсоп, Граевского района, проживает там же.

6. І'РЫЗВАЛЬД Феликс Бзефович, 1909 го.да рождения, капрал бывпгей польской армии, заместитель коменданта повстанческой организации г. ІЩучино, Граевского района, проживает там же.

7. ГРАЕВСКИЙ Александр Леонович, 1919 года рождения, житнль д. Нечково, проживает там же, по аг. данным является одним из руководителей повстанческой организации в Граевском районе.

8. ХЕЛМИНСКИЙ Болеслав Антонович, 1909 года рождения, житель д. Нечково, по аг. данным являвтся связным повстанческой организации в Граевском районе.

9. ПИВКО Станислав Михайлович, 1911 года рождения, в быв. польской армии служил рядовым, ведал диверсионным магазинов, прожиалі в г. Щучино.

Дальнейпие агентурно-следственные мероприатия направлены на вскрытие всех участников повстанческой организации в Граевском и других районах, складов оружия и пाтаба организации, нахо,дяцегося около г. Ломжа.

Имеппуюся агентуру в дл. Жебры, Нечково и г. Шучино направили на установлене местонахождения коменданта Шучиского уезда "СТЕ $\Phi$ АНА".

В этих же целях был завербован арестованный Пивко Станислав, которому в целях запифровки организован побег и он пере- 
веден на нелегальное положение. Пивко направлен со специальном заданием разыска "СТЕФАНА”.

О результатах агентурно-следственных мероприятий сообщу дополнительно.

НАІІДНЫЙ КОМИССАР ВНУТРЕННИХ ДЕЛ БЕЛОРУССКОЙ ССР (podpis) (Л. IIАНАВА)

"26" августа 1940 г.

№ $1 / 5191$

2 От,дел УГБ

М И Н C K

Oryginal, maszynopis.

Źródło: NARB w Mińsku, zesp. 4, spr. 21, t. 2078, k. 297-302.

a Wielkie litery i podkreślenia oryginału.

b Dzień wpisany odręcznie.

1 Prawdopodobnie Stanisław Koniuszy.

2 Prawdopodobnie Marian Szklarski.

\section{Dokument 7}

1940 sierpień 26, Mińsk, - Informacja specjalna ministra spraw wewnętrznych BSRR o likwidacji zbrojnej grupy polskiego podziemia w rejonie Jedwabnego.

$Э Г / 4$

COBEPШEHHO CEKPETHO $^{a}$

СЕКРЕТАРЮ ПК КІ(б) БЕЛОРУССИИ Товарищу IIOHOMAPEHKO

\section{C П Е II-C O O БШ Е Н И E}

В дополнение к № 2/2402 от 24/6 - $1940^{1}$ года доношу:

В результате агентурных мероприятий 24/8 - 1940 г. в 7 часов утра в деревне Конты, Едвабновского района, Белостокской обла- 
сти оперативной группой эикви,дирована бан,дгруппа в составе 6-ти челювек: 2 бандита убиты, 4 захвачены живыми.

Убитыми оказались:

1. МОЩАРСКИЙ Болеслав Витольдович, 1903 года рождения, крестьянин-сере,цняк, бывпий капрал польской армии, житель дер. Канты. Проходит по документам, захваченным при эиквидации пाтаба повстанческой организации в Едвабновском районе, как участник указанной организации по,ц кличкой „Шлифка”.

2. ШИВИНСКИЙ ЯН ЯНОВИЧ, 1914 года рождения, житель дер. Канты, прохо,цит также по документам ликви,дированного пштаба повстанческой организации по,ц кличкой „МАЛЫ КРУК”, „Юзеф”.

Захвачены живыми и арестованы:

1. РОГОВСКИЙ Болеслав Степанович, 1900 года рождения, крестьянин-середняк дер. Канты. Проходит по материалам захваченным при ликвидированного пітаба повстанческой организации в Едвабновском районе, как участник указанной организации, под кличкой „ЯСКОЛКО”.

2. ПОЛЬКОВСКИЙ Антон Болеславович, 1923 года рождения.

3. ХИЛИНСКИЙ Алгксандр Янович, 1914 го,да рождения.

4. РЫДЛЕВСКИЙ Франц Войцехович, 1920 го,ца рождения, житель дер. Хростово, Едвабновского района.

При ликвидации бандгруппы изъято: 2 винтовки, 1 граната и 15 патрон.

О результатах следствия донесу.

НАПОДНЫЙ КОМИССАР ВНУТРЕННИХ ДЕЛ БССР (podpis) ( Л. ШАНАBA)

„26" ь августа 1940 г.

№ $2 / 5691$

гор. М и н с к

Oryginal, maszynopis.

Źródło: NARB w Mińsku, zesp. 4, spr. 21, t. 2078, k. 284-285.
a Duże litery i podkreślenia oryginału.
b Dzień wpisany odręcznie.
1 Raportu autor nie odnalazł. 


\section{Dokument 8}

(1940 wrzesień) a , Mińsk, - Informacja specjalna ministra spraw wewnętrznych BSRR o likwidacji agenta NKWD we wsi Mocarze, rejonu jedwabnowskiego.

\section{COBEP WEHHO CEKPETHO $^{a}$}

СЕКРЕТАРЮ ЦК КП(б) БЕЈОРУССИИ товарищу ПОНОМАРЕНКО

Здесь

\section{II E I - C O O БЩ Е H И E}

6-го октября в 7 часов утра в дер. Мацажи, Едвабновского района, Белостокской области в саду ВЈАДКОВСКОГО Валерия Иосифовича обнаружен труп председателя крестьянского комитета - ЈИПИНСКОГО Иосифа Вацлавовича, 1896 г. рождения, бедняк.

ЈИПИНСКИЙ оказывал помогю органам НКВД по выявлению повстанцев и бандитов.

Штабом контр-революционной повстанческой организации ликвидированной нами в Едвабновском районе, которой руководил БУРСКИЙ, ЈИПИНСКИЙ занесен в книгу, как агент советской разведки (см. наше сообщение № 2/3102 от 24 июня 1940 г.)‥

ЈИПИНСКИЙ изчез при следуюших обстоятельствах:

5/9-40 г. будучи у двойродного брата - ЈИПИНСКОГО Македона, он от него пошел домой. Около 22 часов, проходя мимо сада соседа ВЈІАДКОВСКОГО был пойман, избит и задушен, после чего повешен на его же ремне на дерево. Утром труп был обнаружен лежащим на земле, а на дереве привязан обрывок его ремня.

В убийстве подозреваются - участники повстанческой организации әтой жн деревни - МОЩАРСКИЙ Юзеф - комендант пляцувки (скрывается) его брат МОЩАРСКИЙ Алкцандр Францевич, который 5/9-40 г. был в деревне и изчез после убийства и др.

Всего в этой деревне скрываются 20 челювек членов контр-революционной повстанческой организации, в числе которых находится ВЈААКОВСКИЙ Юзеф, 1922 г. р., и ВЈАДКОВСКИЙ Франтипек, 1920 г. р., оба ВЈІАДКОВСКИЕ проходят по документам, захваченными нами при эикви,дации пाтаба Едвабновской 
повстанческой организации, как ее участники, первый под кличкой „Муха” и второй под кличкой „Зух”. ВЈІ АКОВСКИЕ имеют отца - ВЈІАДКОВСКОГО Валерия, 46 лет, крестьянин зажиточный, последний нами арестован, как пособник повстанцам.

Приняты меры разыска и ареста выпе перечисленных участников повстанческой террористической организации.

\section{НАПОДНЫЙ КОМИССАР ВНУТРЕННИХ ДЕЈ (podpis) (Л. ПАНАВA)}

№ $2 / 6147$

Oryginał, maszynopis.

Źródło: NARB w Mińsku, zesp. 4, spr. 21, t. 2079, k. 79-80.

a Datę ustalono na podstawie numeracji informacji.

b Wielkie litery i podkreślenia oryginału.

1 Por. dok. 3.

\section{Dokument 9}

1940 październik 10, Mińsk, - Informacja specjalna ministra spraw wewnętrznych BSRR o okolicznościach przyjazdu do Biategostoku ptk. Adama Obtułowicza i jego aresztowaniu.

\section{СЕКРЕТАРЮ ІІК КП(б) БЕЈОРУССИИ товарищу ПОНОМ АРЕНКО (Лично) ${ }^{\mathrm{a}}$}

г. Минск

По поступившим агентурным данным в Белосток нелегально прибыл подполковник бывшей польской армии - ОБТУЈІОВ ИЧ ${ }^{1}$, с целю устновления связи с повстанческими организациами в городе Белостоке.

Шо этим же данным нам стало известно, что ОБТУЈІОВИЧ, будучи интернирован бывшими литовскими властями, при переходе границы помещен в лагерь. В момент вторичного прихода частей PККА в Каунас, он в числе других офицеров быв. польармии бежал из литовского лагеря и в июне 1940 года прибыл в г. Вильно, 
где связался с участником повстанческой организации СТАВОВСКИМ Вла.циславом ${ }^{2}$, через которого, в конце августа, установил связь с представителем Виленского повстанческого штаба ВЕСЛОВСКИМ ${ }^{3}$.

ВЕСЛОВСКИЙ информировал ОБТУЛОВИЧА, что существовавшая связь Виленского повстанческого штаба с националистическими повстанческими организациами на территории западных областей БССР, за последнее время нарушена в виду разгрома последних, поэтому он считает необходимым послать его в Белосток, для восстановления этих связей. Пре.цложение ВЕСЛОВСКОГО ОБТУЛОВИЧ принял.

Дэя нелегального перехода из Литвы в БССР - ВЕСЛОВСКИЙ снаб.дил ОБТУЛОВИЧА фиктивными документами на имя СКУБАЛО Стефана Алексан,дорвича и дал 500 руб. денег.

Тогда же ВЕСЛОВСКИЙ связал ОБТУЛОВИЧА с участником организации - переправщиком КРУК, которому поручил нелегально перебросить ОБТУЈІОВИЧА на территорию БССР.

Перед отправкой ВЕСЈІОВСКИЙ дал ОБТУЈІОВИЧУ явку в горо.ц Белосток, по адресу - ул. Поперечная, дом № $13, \mathrm{k} \mathrm{KE-}$ ЖЕЛЬ Ришар,ду Осиповичу, через которого ОБТУЛОВИЧ должен был установить связь с повстанческими организациами в Белостоке.

В начале сентября 1940 года ОБТУЛОВИЧ прибыл в Белосток, где по указанной явке связался с КЕЖЕЛЬ. О.днако последний связать его с повстанческими организациами не сумел, по причине о которой ему говорил ВЕСЛОВСКИЙ.

В последсвии КЕЖЕЛЬ связал ОБТУЈІОВИЧА с участником организации, нашим агентом „ВОЛК” ${ }^{4}$ которому поручил связать ОБТУЛІОВИЧА с к/р по.цпольем.

В течение трех недель ОБТУЛОВИЧ совместно с „ВОЛК” пытались установить связь а подпольем, но результатов эти попытки не ,дали.

Получив све.дения, что ОБТУЛОВИЧ намеревается нелегально пробраться за кордон, мы решими его секретно снять.

В допросе ОБТУЛОВИЧ подтвердил имевшиеся в нашем распоряжении агентурные данные, причем после,дние были документально перекрыты, так как при личном обыске у ОБТУЛОВИЧА был из'ьат документ на имя СКУБАЈІО Стефана Александровича.

ОБТУЛОВИЧ-СКУБАЛО пока развернутых показаний не ,дал. В этом направлении мы ведем работу, изучая вопрос его вербовки 
и оставлении в БЕЈIOCТОКЕ, с целью перехвата через него связей подпольных организаций на территории западных областей БССР и за кордоном.

О результатах сообщу.

НАІІДНЫЙ КОМИССАР ВНУТРЕННИХ ДЕЈ БЕЈІОРУССКОЙ ССР (podpis) (Л. IIAНАВА)

„10" о октября 1940 года

№ $1 / 6498$

2 Отдел УГБ - Минск

Oryginal, maszynopis.

Źródło: NARB w Mińsku, zesp. 4, spr. 21, t. 2080, k. 31-33.

a Wielkie litery i podkreślenia oryginału.

b Dzień wpisany odręcznie.

1 Ppłk Adam Obtułowicz, ps. Leon, Karol, szef sztabu i z-pca Komendanta Wojewódzkiego SZP-ZWZ w Wilnie. W końcu marca $1940 \mathrm{r}$. na polecenie KG ZWZ udał się z mjr. J. Roczniakiem do woj. nowogródzkiego w celu zorganizowania komendy okręgu. Latem 1940 został aresztowany. Przebywał w więzieniu w Mińsku i Moskwie. Pod presją zgodził się na współpracę z NKWD, lecz po zwolnieniu chcąc uniknąć współpracy ukrywał się. Wyśledzony przez NKWD zginął wiosną $1941 \mathrm{r}$. podczas próby zatrzymania pod nazwiskiem Stefan Skubała.

2 Nazwisko nie występuje w polskich źródłach.

${ }^{3}$ Mjr Aleksander Krzyżanowski.

${ }^{4}$ Nazwisko nie ustalone.

\section{Dokument 10}

1940 listopad 8, Mińsk, - Informacja ministra spraw wewnętrznych BSRR o okolicznościach aresztowania członków sztabu okręgu białostockiego ZWZ.

У скорите делю.

COBEPIШEHHO CEKPETHOa

ІІономаренко

(podpis)
СЕКРЕТАРЮ ІІК(б) БЕЈІОРУССИИ Товарищу IIOHOMAPEHKO

В дополнениек моемй № 1/5191 от 26-го августа 1940 го.да ${ }^{1}-$ сообщваю: 
Именоцимися в распоряжению НКВ.Д БССР материалами установлено, что вскрытая контрреволюционная польская националистическая организациа в Белостокской области возглавляемая офицером б. польской армии под кличкой „СУСЛО”, „АНТОНОМ”, является ответвлением заграничного центра „Союза вооруженной борьбы” (СВБ), руководимого „польским правительством” в Англии во главе с генералом СИКОРСКИМ и генералом СОСНКОВСКИМ.

.Документами по,цтверждается, вскрытая контрреволюционная организация направляется „Союзом вооруженной борьбы” через коменданта территории оккупированной немцами и регулирующими делгами территории округов № 2 (Белосток) и № 3 (Львов) полковника РОВЕШКОГО, по.д кличкой „РАКОНЬ”, находящегося в гор. Варшаве.

Возникновение вскрытой контрреволюционной организации относится к январе-феврале 1940 го.да, т.е. с момента посылки полковником „РАКОНЬ" своих эмиссаров „СУСЈIО" Антона и „Стефана" (Шкларского) с заданием объединить все существовавшие на территории западных областей БССР повстанческие националистические группы и организации по.д общим руководством „СВБ”.

В процессе разгрома целюго ряда повстанческих организации в западных областях БССР установлено, что в состав пाтаба Белостокского округа № 2 „СВБ” входят:

1. "СУСЈО" Антон, он же „МАЗЕШКИЙ", „МАРЕШКИЙ”, „СКАВРОНИК”, „МАРУССКИЙ” и „НЕЧУЯ".

2. ІІКЈЯРСКИЙ, он же „СТЕФАН”, „БАСЕВИЧ” и „ЯАІКОВСКИЙ" 3 .

3. ГЛЫМБОШКИЙ, он же „СТАНИСЛАВ”, „ПЈЕВО” и „ЭКKEPT".

4. БУРЫ Я,цвига, она же „БАЛИШКАЯ СОФИЯ”, „САБИНА” и „ИОАННА”.

Структура повстанческого Белостокского округа № 2 имеет следующее организационное построение:

1. Комен,данты уездных организаций в старых административных делениях с 2-3 заместителями.

2. Коменданты районов - объединяғоцие 4-5 гмин.

3. Коменданты гмин (волостей).

4. Комен,данты пляцувок об'ьединяюпие группы деревенских населенных пунктов.

Осушествляя намеченные агентурно-оперативные мероприатия, 
направленные на розыск руководящего пाтаба Белостокского повстанческого округа № 2 СВБ и перехвата его в руки нашей агентуры, нами в начале октября 1940 г. установлен и негласно снят комен,дант Шучинской контрреволюционной организации ЗВАЗДОВСКИЙ Станислав Антонович. 1909 года рождения, подпоручик запаса быв. польской армии, в последнее время работал директором неполной средней школы в д. Климапевница, Граевского района, у которого обнаружено было ря,д пиифрованных документов: приказы, ключи к пифру, явочные квартиры членов пाтаба округа и пароли.

На допросе ЗВЯАДОВСКИЙ показал, что после ликвидации нами одного из активных участников повстанческой организации, члена окружного штаба № 2 СВБ „СТАНИСЛАВА” в июле месяце 1940 года, он в конце августа представителем от „полского правительства" за границей для работы на территории западных областей БССР - „СТЕФАНОМ" при вербовке, в подтверждение своей эичности, прдъявил документ за подписью и печатью на неболыпом локуске метерии.

ЗВЯЗДОВСКИЙ назвал как коменданта округа № 2 СВБ, „СУСЛО" Антона, который находится на территопии западных областей БССР, но строго законспирован, скрывается, маскируясь пгод разными фамилиами и кличками, систематически меняя местожктельства.

Он же назвал явочные квартиры курьеров, через которых имел связаться с членами окружного пгтаба - „Я двигой” и „Стефаном”.

Гвяздовскийс нами был завербован под кличкой „ЩУР” и по его материалам в ночь с 15-е на 16-е октября 1940 года нами сняты:

1. Член пітаба округа № 2 „Я,двига" на явочной квартире в д. Вишеваты, Моньковского района, у участника организации - ВЫШЕВАТОЙ Веронки.

При обыске в жакете принадлежащем „Ядвиге” обнаружен „срочный приказ" по СВБ, тезисы обзора международного и внутреннего положения, приказ № 15 от 1 октября 1940 года за поддписью „Нечуя” и другие зашифрованные записи.

2. Член пाтаба округа „Стефан” на явочной квартире на хуторе в дер. Климашевница, Граевского района, в доме участника к/р организации МРАЧКОВСКОГО.

При личном обыске в пиджаке обнаружено удостоверение напечатанное на шелкомом сером лоскуте, на польском языке и заверен- 
ное печатью - следуюшего содержания:

„Назначаю гражданина IШКЈЛ РСКОГО ,делегатом СВБ на Белостокское воеводство. ІШКЈІ ЯРСКОМУ приказываю привести в порядок акцию независимости на этой территории.

Комендант оккуп/ации/ нем/мецкой/

и регулирующий делгами территории 2 и 3 РАКОНЬ".

На этих явочных квартирах были оставлены засады. В результате 16 ноября с.г. у ВЫШЕВАТОЙ за,держан курьерь штаба округа МЕНДЕЛЕВСКИЙ Ежи Романович, 1921 года рождения, явившийся на связь к БУРЫ Я,двиге, имел на руках „срочный приказ”, суцность коего сводится:

1. К призыву продолжать борьбу с „оккупантами”.

2. $K$ по,цготовке длля вооруженного выступления.

3. К борьбе за полную „незвисимость” Полыни и решительный отказ от коміромиссов могущих быть предположенными „оккупантами".

4. $\mathrm{K}$ категорическому отказу от какого-либо участия в возможном германо-советском конфликте.

5. K противо,действию влияния германизации и русификованию поляков.

6 . $K$ саботажу на предприятиях и учерждениях.

7. К несопротивлению призыву в РККА и разложению воинских частей изнутри ${ }^{4}$.

На предварительном допросе „СТЕФАН” ШКЈЯРСКИЙ Марян Станиславович 1910 го,да розкдения, подпоручик б. польской армии, урожденец Краковского уез.да, показал, что он завербован в СВБ в декабре 1939 года капитаном Салищеневским Та,деушом в г. Варшаве, а в феврале 1940 г. полковником РАКОНЬ направлен в западные области БССР для организационной повстанческой деятельности.

„Я,двига" - БУРЫ Я двига Бог,дановна, 1910 го.да рож,дения, инжинер-агроном, из помешиков, показала, что она лично связалась с Варшавским центром СВБ, по заданиям которого работала совместно с "СУСЈIO" Антоном и „Стефаном".

Развернутых показаний ШКЛЯРСКИЙ И БУРЫ пока не дали. Дальнейшие агентурно-оперативные мероприятия направляяем на розыск и поимку „СУСJIO" Антона, через агента „ЩУР”.

В зависимости от показаний БУРЫ и ІШКЈЯРСКОГО, бу,дет 
релюо вопрос о возможности использования их с целью перехвата руководства СВБ.

О результатах сообщу.

\section{НАРО.ДНЫЙ КОМИССАР ВНУТРЕННИХ ДЕЛ БЕЈIОРУССКОЙ ССР (podpis) (Л. IIAHABA)}

"8"d ноября 1940 года

№ $1 / 6787$

г. Минск

Отпеч. в 5 экз

1-й экз тов. БЕРИЯ

2 -й " тов. ФЕЈІОТОВУ

3-й " тов. IIOНОМАРЕНКО

4 и $5 "$ - в делах 2 Отдела УГБ

Oryginał, maszynopis.

Źródło: NARB w Mińsku, zesp. 4, spr. 21, t. 2080, k. 177-183.

a Wielkie litery i podkreślenia oryginału.

b Dekretacja i podpis napisane czerwonym ołówkiem.

c Nazwisko agenta wpisane odręcznie.

d Dzień wpisany odręcznie.

1 Por. dok. 6.

2 Por. przypis do dok. 1.

3 Pomyłka. „Jackowski” to ps. por. F. Skowronka.

${ }^{4}$ Dokumenty te $\mathrm{w}$ przekładzie na język rosyjski znajdują się w wymienionej teczce na k. 184-192. 


\section{Dokument 11}

1940 grudzien 17, Mińsk, - Raport specjalny ministra spraw wewnętrznych BSRR o zgłaszaniu się dobrowolnie do NKWD cztonków polskiego podziemia.

3П. 4.

COBEPUEHHO CEKPETHO $^{\mathrm{a}}$

Очень интересно

Пономаренко

СЕКРЕТАРЮ ШК(б) БЕЛОРУССИИ товарищу ПОНОМАРЕНКО (Лично) гор. М и н с к

\section{CПЕЩСООБIҢЕHИЕ}

В результате принятых агентурно-оперативных мероприятий, ря.д повстанцов, участников к/р организации, находивпиися на нелегальном положени и, явились в органы НКВД с „повиной”, так например:

10 декабря 1940 года в Едвабновское РО НКВД по Белостокской области, явилось 19 человек участников повстанческой организации „Союз вооруженной борьбы”.

Явивпиеся с „повиной” нами отпущены домой. В результате их освобождения и дальхейних агентурно-оперативных мероприятий в Едвабновское РО НКВД стами являться другие скрывающиеся участники контреволюционных организаций. Так из деревни Куче- Дуже явилось 12 повстанцев, из деревни Шелюты 15 человек, из деревни Безры 6 человек.

После освобождения этих рядовых повстанцев, стали являться командиры дружин повстанческой организации: КОНОПКО Вацлав Юзефович, СКРИПКОВСКИЙ Чеслав Шотапевичс - б. капрал, КОВАЛЕВСКИЙ Казимир Юзефович, МЕЧКОВСКИЙ Казимир Владиславович - бывний комен,дант и командир пулеметного взво,да, активный повстанец, КОСАКОВСКИЙ Ян Владиславович.

15 декабря 1940 года в это же РО НКВД явилось с „повиной” щесть человек участников к/р организации - „Союз вооруженной борьбы". Причем, явивпиеся изъявили желание принять участие в выборах.

За периодц с 10 ноября по 15 декабря всего сдалось 70 человек.

Все явивпиеся нами детально допрошены, по выявлению их ру- 
ководства, оружия и практической контрреволющионной деятельности.

Сдавшиеся участники повстанческой организации „Союз вооруженной борьбы" взяты нами в активную агентурную разработку.

Прово,дим ,дальнейшую агентурно-оперативную работу по разлољкению скрываююцихся бан,дитских групп повстанцев.

О результатах сообщу.

\section{НАРОДНЫЙ КОМИССАР ВНУТРЕННИХ ДЕЛ БЕЈIОРУССКОЙ ССР (podpis) (Л. IІАНАВА)}

„17" , декабря 1940 го,ца.

№ $1 / 8593$

2 От,д. УГБ - МИНСК

отп. в 4-х экз.

экз. № $1-$ г. Москва - т. Берия

, № 2 - г. Минск - т. Пономаренко

" № 3 - делах 2 От,д-ния

" № 4 - делах Секр. 3 Отдела

Oryginał, maszynopis.

Źródło: NARB w Mińsku, zesp. 4, spr. 21, t. 2081, k. 181-183.

a Duże litery i podkreślenia oryginału.

b Adnotacja odręczna, czerwonym ołówkiem.

c Tak w oryginale.

d Dzień tygodnia i numer wpisane odręcznie. 


\section{Dokument 12}

1940 grudzień 26, Mińsk, - Informacja ministra spraw wewnętrznych BSRR o ujawniajacych sie cztonkach polskiej organizacji podziemnej $w$ rejonie Jedwabnego.

COBEPШЕНHO CEKPETHO ${ }^{a}$

СЕКРЕТАРЮ ШК(б) БЕЛОРУССИИ товаришу ПОНОМАРЕНКО (лично) гор. Минск

В дополнение к № 1/8439 от 17.12.1940 года ${ }^{1}$ сообщаю:

В результате проведения дальнейших агентурно операционных мероприятий по разложению скрывагоихся бандитских групп повстанцев в Едвабновском РО НКВД, Белюстокской области, с 16 по 24 декабря с.г. дополнительно явилось с „повиной” 16 челгвек, находивпихся на нелегальном положении участников контрреволюционной повстанческой организации „Союз вооруженний борьбы" и 5 глав семьи јесников-оса,дников, скрываюощихся от выселения.

Всего явилось с „повиной” в Едвабновском РО НКВ Д с 10 по 24 декабря 86 участников организации, из них два коменданты пляцувок, 6 комен,дантов дружин и 78 рядовых участников организации.

Для агентуроной разработки явивпиися с „повиной” и дальнейпाей разложенчекой работы среди продолжающих скрываться, из числа явивпгтхся в качестве агентов завербовано 19 человек.

Кроме этого завербован 1 осведом, который озадачен на разработку явивіпихся 5 глав семей „оса,дников-лесников”.

О результатах сообщу.

\section{НАРОДНЫЙ КОМИССАР ВНУТРЕННИХ ДЕЛ БЕЛОРУССКОЙ ССР (podpis) (Л. ШАНАВА)}

„26" в декабря 1940 года.

№ $1 / 8985$

2 Отдел УГБ - МИНСК

Отп. в 4-х экз. 
экз. № 1 - г. Москва - т. Берия

" № 2 - г. Минск - т. Пономаренко

" № 3 - делгах 2 Отд-ниа

" № 4 - секр. 2 От.деления

Oryginał, maszynopis.

Źródło: NARB w Mińsku, zesp. 4, spr. 21, t. 2081, k. 217-218.

a Duże litery i podkreślenia oryginału.

b Dzień wpisany odręcznie.

1 Por. dok. 11.

\section{Dokument 13}

1941 marzec 7, Mińsk, - Raport ministra bezpieczeństwa państwowego BSRR o ZWZ na pótnocno-wschodnich ziemiach Polski w latach 1939-1941.

COBEPШEHHO CEKPETHO $^{\circ}$

$3 \Pi$

СЕКРЕТАРЮ ШК КП(б) БЕЈІОРУССИИ товаришу ПОНОМАРЕНКО (Лично)

г. М и н с к

\section{ДОКЈАДНАЯ ЗАПИСКА}

Сообщаю: в процессе агентурно-операционных и сле,дственных мероприятий по дезу вскрытой и частично ликвидированной контрреволюционной организации „Союза вооруженной борьбы” были арестованы руководители штаба „СВБ” - Цисик А.дам, он же Шклярский, он же Басевич, известный среди участников организации под кличкой „Стефан”; Игла-Иглинский по.д кличкой „Антоний”; Бури Ядвига, она же Валицкая София; представитель штаба руководства окружного центра - Јюдвиг, курьер организации Погожельский и другие руководители уез.дов гмин, пляцувок.

Таким образом, в основном Белостокский штаб „СВБ” был разгромлен. 
Однако, в результате дальнейпих агентурно-операционных мероприятий было установлено, что на территории Замбровского района в дер. Тыбора был сформирован птаб „СВБ”, во главе которого стал ранее нам известный эмиссар варшавского центра „СВБ” - Шульц Ян Иванович, по.ц кличкой „Януп”. Параллельно с ним также был взят в агентурную разработку активный участник повстанческого движения Болочко Сильверст Ксаверович - как его связь, был взят под наружное наблюдение неизвестный, который, пытаясь уйти от разведки, открыл стрельбу и, попав в безвыхо,цное положение, Іюкончил самоубийством ${ }^{1}$.

При опознании труда установлено, что покончивпий самоубийством явл.яется разыскиваемый нами эмиссар Варшавского центра Скубалю Стефан, он же Обтулович А.дам А.дамович.

Зная Обтуловича как активного участника организации „Союза вооруженной борьбы", нами были арестованы установленные связи Обтуловича, причем, в числе этих связей оказалися лица, активно разрабатываемые как участники „СВБ”.

В числе других был арестован Мазуркевич Э.дуар.д, капрал бывпей польской армии, комен,цант Гроденской организации „СВБ”.

Следствием и дальнейшими агентурно-операционными мероприятиями установлены и арестованы - Шульц Ян Иванович, по,ц кличкой „Януп”, поручик бывпей польской армии, руководитель повстанческой „обпгары” (территория западных областей БССР).

По,цхорский Алексан,цр-Георгий Константинович, 1912 го,ца рождения, по.дпоручик бывпей польской армии, эмиссар по.дпольного Варпгавского центра, связист по организации „СВБ” Белорусской и Литовской ССР.

Барковская София, она же Скавроник Мария, она же Венгелевская Мария под кличкой „Марта”.

На следствии Шульц Ян и Подхорский показали, что после разгрома Белостокского повстанческого округа и ареста его руководителей - „Антония”, „Стефана”, „Бури”, „Витольда”, он же „Матей Самура", по инициативе Поцхорского в квартире Свеницкого Казимира Францевича (арестован) в дер. Тыбора, Замбровского района, осенью 1940 года было созвано совещание, где присутсвовали: Шульц Ян, Барковская София и комендант Ломжинского повстанческого повята - Яцковский, он же Скавроник по.ц кличкой „Франципек” (убит при задержании) $)^{2}$. 
На этом совещании был сконструирован новый повстанческий Белостокский штаб в составе:

1. Шулььц Яна

2. Подхорского Александра-Георгия

3. Милевский под кличкой „Мстислав” (скрывается) $)^{3}$

4. Барковская София

5. Ставецкий Стефан под кличкой „Плеве” (скрывается).

Здесь же среди руководящего состава „СВБ” были распределены обязанности следуюгцим образом:

Шульц было поручено руководство всей повстанческой деятельностью на территории западных областей Белоруссии и вручено удостоверение Варішавского гштаба „СВБ” за подписью „Роконь” - полковник бывшей польской армии Равецкий Стефан (находится в гор. Варшаве), выданное на имя „Матей Самура", где указывалось, что "Матей Самура" назначается комендантом Белостокского воеводства „СВБ” и ему также поручается организовать филиалы „СВБ” на территории Полесского, Новогрудского воеводств до Јиитовской границы. Одновременно Шульц было поручено руководство 2-го отдела штаба разведки и контрразведки.

На Подхорского были возложены обязанности шефа пाтаба организации и руководство 1-м отделюм (организационные дела).

На Милевского - „Мстислав” возложены обязанности коменданта Белостокского воеводства и руководство 3-м отделом пштаба (оружие и комплектование кадров). Он же был назначен заместителем Шульца.

На Барковскую Софию возложено руководство 5-м отделом гштаба (связь).

На Ставецкого Стефана „Плеве” - руководство 4-м отделюм ıштаба (санитарно-хозяйственная слыжба).

Следствием также установлено, что оставішиеся документы (удостоверения - изъяты) на имя „Нечуя” Игла-Иглевского и „Матей Самура" - Спыхальский, в квартире названного Свеницкого Казимира - по условленности руководства Белостокского гштаба „СВБ” имели полныю силу в руках находящегося.

В процессе дальнейшей операции арестовано 80 участников "Союза вооруженной борьбы", из них курьер варішавского центра "СВБ” Каминская Дорота, 1913 года рождения, дочь крупного варшшавского купца, пришедшая нелегально на территорию Белорусской ССР из Германии 21 февраля 1941 года, в целях передачи до- 
кументов в Белостокский штаб „СВБ”, „- „Мстиславу” и „Янушу”, и в Львовский пाтаб „Конраду”.

При обыске у нее узъято: 660 американских долларов, 12 тысяч рублей совзнаками, в каблуках ботинок у нее найдено 1000 американских долларов и шифродокументы от 17-го февраля 1941 года.

Каминская показала, что 60 доллгаров и 12 тысяч рублей денег она долюкна была передать „Мстиславу” и „Янушу”, а шифродокументы и 1000 долларов в Львовский штаб „Конраду”, по адресу гор. Львов, ул. Рея, 5 - Малечинская Эмилия.

Маевский Адам, под кличкой „Казик”, 1904 годда рождения, торговец, переправцик Варшавского штаба „СВБ”, по заданию птаба на нашу сторону переправиј „Антония”, „Матея Самура", Каминскую и других.

\section{Районные коменданты города Белостока:}

1. Врубель Петр, 1916 года рождения, капрал бывшей польской армии.

2. Кожецкий Витольд Михайлович, 1916 го,да рождения, капрал бывшей польской армии.

3. ІШанявский Вацлав, 1914 го,ца рождения, по,дхоружий бывшей польской армии.

4. Сосновский Леонид, 1915 года рождения, капрал бывпей польской армии.

5. Берна,дский Та,деуш, 1910 года рождения, капрал бывшей польской армии.

6. Погожельский Мечислав, 1917 года рождения, капрал бывшей појьсккой армии.

По гор. Гродно арестованы следукощие коменданты раионов:

1. Пухальский Адольф, 1898 года рождения.

2. Эйсмонт Игнатий, 1899 года рождения.

3. Сигилевский Мечислав, 1909 года рождения.

4. Перко Антон, 1900 года рождения, плютоновый бывішей польской армии.

5. Низеол Станислав, 1909 года рождения, плюотоновый бывшей польской армии.

На следствии арестованные коменданты гг. Белостока и Гродно показали: что город Белосток делится на районы, во главе которых стоят коменданты. В свою очередь комендантуры строилися по орга- 
низационному принципу: Комендант района, заместитель коменданта раиона, разве.дчик, коменданты пунктов, улиц, фольварков.

В городе Гродно было сформировано 6 комендантур, т.е. 6 районов, во главе которых поставлены коменданты.

В свою очередь районные комендантуры строились по структуре: район, пункты, дружина, секция, тройка.

Наря,ду с территориальным делением города на районы, штаб „СВБ” ставит перед собой задачу организации повстанческих групп на каждом предприятии, причем если предприатие насчитывает более 300 человек мужчин, то оно является отдельным районом во главе с комендантом, заместителем, разведчиком и двумя-тремя помощниками коменданта.

Из агентурных и следственных метериалов, а также из'ьятых документов, установлено, что „СВБ”, повстанческие ячейки, группы и комендатуры насаждали на военных, стратегических и промышленных объектах, как-то: на транспорте, объектах связи, складских хозяйствах и т.д.

Белостокский окружной штаб „Союза вооруженной борьбы” был организационно связан с Виленским центром „СВБ”, в штаб которого, по данным материалам следствия, входят:

1. „Ладына", он же "Сулик", полковник бывппей польской армии ${ }^{4}$.

2. Кжижановский - майор бывшей польской армии, ад'ьютант пІтаба, его клички: „Олесь”, „Веселовский", „Брилло” 5.

3. Каминский Владислав - советник пाтаба ${ }^{6}$.

4. Кухарский - ксендз, руково,дитель ордена иезуитов, советник штаба?.

5. Заремба - капитан бывпей польской армии, советник пाтаба ${ }^{8}$.

Постоянная связь Виленской организации с Белостокской осуществлялась через специальных курьеров Белостокской и Виленской организаций. Для курьеров Белостокской организации в гор. Вильно имелось 3 явочных квартиры и пароль.

1. Виленская ул., 7, обувной магазин Можейки, пароль на эту квартиру: „Принес письмо от Каликста”. ШПивлис, работник этого магазина спрапивает: „На чей адрес?”, ответ „До Малика, прошу вручить".

2. У лица Каньанью, 32 , Хелина Чернецкая - пароль тот же.

3. Антикольская, 21, Наргавецкий Станислав: „Прислал меня Каликст". 
Для виленских курьеров в Белостоке имелась явочная квартира по ул. Козлова, д. 4, Моники Тарасевичувны. Пароль: „Пришел от Кароля".

Помимо связистов-курьеров Виленская организация имеет 4 радиопередатчика, по которым осуществляет связь с варшавским центром "СВБ”.

Арестованный Подхорский на допросе показал, что Виленский гштаб „СВБ” установил связь с английским и японским послами в гор. Ковно. Связь осуществлялась непосредственно через членов штаба „СВБ” - Кжижановского, по прямому заданию „ЈТадына”.

В сентябре месяце 1940 года Кжижановский имел встречу с английским и японским послгами в гор. Ковно.

У ряда арестованных участников „СВБ” из'ъяты документы организации [определявшие] ее задачи, денежные отчеты, пароли, шифровки и т.д.

Из документов, изьятых у Каминской Дороты, видно, что Варшавский центр намерен формировать новый повстанческий округ по бывшему Новогрудскому воеводству. Из этих же документов установлено, что „СВБ” производил тाцательный отбор вербуемых в организации, придаавая националистический характер организации, в то же время запрещая вербовать в организацию учеников, несовершеннолетних, русских, евреев, алкоголиков.

Вместе с тем, в своих приказах „СВБ” обязывал участников организации войти в доверие к общественности, запрещая проявлять какое'ъ-либо недовольство, отрицательные высказывания и т.,д.

Вместе с документами, путем тпцательного обыска, обнаружена и из'ьята подпольная техника, оружие и боеприпасы, как-то:

1. Коротковолновый радиопередатчик;

2. Пишуцих машинок - 2;

3. Пулеметов станковых - 7;

4. Миномет - 1;

5. Гранат ручных - 7;

6. Винтовок польских -22 ;

7. Штыков к винтовкам - 6;

8. Патронов боевых - 17500 гштук;

9. Военное снаряжение, по,дсумки, противогазы, прибор для чистки оружия, седла и т.д.

Все из'ьатое оружие, припасы и снаряжение хранилось в 4-х складах, устроенных в земле, тпательно замаскированные. 
Из'ьатое оружие, боеприпасы и снаряжение находилось в полной сохранности и пригодно для употребления.

Дальнейшие агентурно-операционные и следственные мероприятия направляем на пюлную ликвидацию „СВБ”, выявление, из'ьатие орузкия и подіольной техники.

IIPИЈОЖЕНИЕ: коІии из'ьятых документов на $27^{\text {b }}$ листах $^{9}$

\section{НАРОДНЫЙ КОМИССАР ГОСУДАРСТВЕННОЙ БЕЗОІІАСНОСТИ БЕЛОРУССКОЙ ССР}

(IIAHABA)

7 марта 1941 года.

№ $3 / 2462^{c}$

2 Отдел УГБ - Минск

отті. в 4-х экз.

экз. № 1 - г. Москва - т. Меркулову

экз. № 2 - г. Минск - т. Пономаренко

экз. № 3 - делах 2 отд-ня

экз. № 4 - делах Секр. 2 Отделга

Oryginał, maszynopis.

Źródło: NARB w Mińsku, zesp. 4, spr. 21, t. 2434, k. 1-12.

a Wielkie litery i podkreślenia oryginału.

b Liczba wpisana odręcznie.

c Dzień tygodnia i nr wpisane odręcznie.

${ }^{1}$ Według innych dokumentów i relacji płk Obtułowicz został zabity podczas zatrzymania w Grodnie.

2 Właściwe: Franciszek Skowronek, ps. Jackowski.

3 Właściwe: Władysław Liniarski, ps. Mścisław.

${ }^{4}$ Ppłk Nikodem Sulik.

${ }^{5} \mathrm{Mjr}$ Aleksander Krzyżanowski.

${ }^{6}$ Ks. Kazimierz Kucharski.

7 Mjr Władysław Kamiński.

8 Brak danych.

${ }^{9}$ Kopie dokumentów są w wymienionej teczce, k. 13-30. 


\section{Dokument 14}

1941 kwiecień 26, Mińsk, - Informacja uzupetniajaca ministra bezpieczeństwa państwowego BSRR o wykryciu cztonków polskiego podziemia w rejonie Śniadowa.

$3 \Pi .4$.

\section{COBEPШЕHНO CEKPETHO $^{a}$}

\section{СЕКРЕТАРЮ ПК(б) БЕЛОРУССИИ товарищу ПОНОМАРЕНКО (Лично) г. М И Н С К}

По данным агентуры было установлено, что житель деревни Козики, Сня,довского района, Белостокской области, - СЕШПУТОВСКИЙ Юзеф Феликсович, в проплом руково,цитель партии „Наро.довцы", в месте со своим сыном СЕШПУТОВСКИМ Викентием, ведут антисоветскую агитацию, высказывают террористические намерения и занимаются сбором оружия для повстанческой организации.

На основании этих ,данных СЕШПУТОВСКИЕ Юзеф и Викентий в конце марта 1941 года были арестованы.

Будучи допрошены по существу дела, СЕШПУТОВСКИЕ назвали себя участниками к/p повстанческой организации, в которую были завербованы летом 1940 года жителем ,д. Козики - ЯІДЕМСКИМ Люцианом по, кличкой „БЖЕЗО” являющегося руководителем организации (находится на нелегальном полюжении).

От „Бжезо” СЕШПУТОВСКИЕ получили за,дание собрать оружие для повстанческих целей.

Проведенным обыском у СЕШПУТОВСКИХ было обнапужено и из'ьато: 5 винтовок, 64 гранаты и 1020 пітук винтовочных патрон.

В числе участников повстанческой организации СЕШПУТОВСКИЕ назвали 17 челювек.

Дальнейпие агентурно-следственные меропрития направлены на розыск „БЖЕЗО”, выявление всех участников повстанческой организации, установление связей с другими к/р формированиями, обнаружению и из'ьятию оружия.

О результатах сообщу. 


\section{НАРО.ДНЫЙ КОМИСС̈АР \\ ГОСУДАРСТВЕННОЙ БЕЗОІІ АНОСТИ БЕЈIOРУССКОЙ ССР (podpis) (JI. IIAHABA)}

„26” апреля 1941 го.да.

№ $3 / 3 / 411$

3 Управление НКГБ - МИНСК

Отп. в 4-х экз.

Экз. № 1 - г. Москва - т. Меркулову

2 - г. Минск - т. Пономаренко

3 - в делах 3 Отдела

4 - Секр. 3 Управления

Oryginal, maszynopis.

Źródło: NARB w Mińsku, zesp. 4, spr. 21, t. 2430, k. 129-130.

a Wielkie litery i podkreślenia oryginału.

b Dzień wpisany odręcznie.

\section{Dokument 15}

1941 kwiecień 29, Mińsk, - Informacja ministra bezpieczeństwa państwowego BSRR o aresztowanych cztonkach $Z W Z w$ okręgu biatostockim.

$3 \Pi .4$.

COBEPIEHHO CEKPETHO ${ }^{a}$

СЕКРЕТАРЮ ІІК КІ(б) БЕЈІОРУССИИ товарищу IIОНОМАРЕНКО (Лично)

гор. Минск

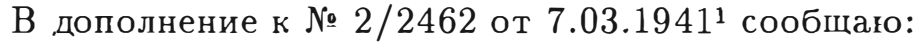

В соответствии с намеченным пјаном агентурно-операщионных мероприятий по разработке и ликви,дации к/р повстанческой организации „Соғоз ворруженной барьбы”, принятыми мерами нами арестовны находившиеся на нелегальном положении: 
1. БРУЛИНСИЙ Владислав Войтехович, 1915 года рож,дения, поляк, подпоручик б. польской армии, бывший комендант организации "СВБ" о городу Ломжа, известный под кличкой „Оскарь".

2. ЗАРЕМБА, он же БУЧИНСКИЙ Ян Юзефович, 1914 года рождения, полюк, подпоручик б. польской армии, бывший комендант уездной Ломжинской организации „СВБ”, последние время был назначен комендантом "СВБ” по Шучинскому уез,ду.

3. ТАРНАІІКИЙ Владислав Янович, 1907 года рождения, поляк, уголювный элемент, при польской власти неоднократно су.дим за воровство, в общей сложности на 24 года, являлся заместителем уездного комен,данта ЗАРЕМБО.

Агентурно-сле,дственным путем установлено, что после произведенного разгрома второго штаба Белостокского повстанческого округа „СВБ”, оставшиеся на свободе члены этого штаба - МИJЕВСКИЙ, кличка „Мстислав"2 и СТАВЕІКИЙ Стефан, кличка "ІІЛЕВЕ”, внов назначили уездных комендантов и через них начали об'ьединять раионные организации „СВБ” по,ц свое руководство.

Допросом БРУЈИИНСКОГО установлено, что он по приказу „Мстислава” назначен комендантом „СВБ” по Белостокскому уез.ду по,д кличкой „Владек”.

БРУЈИИНСКЙ назвал известных ему вновь назначенных уез,дных комендантов, по Шучинсковму уез.ду - ЗАРЕМБО, по Јомжинскому уез,ду - Вонсик ${ }^{3}$ (находится на нелегальном положении) и по Волковыскому уез,цу - „Плеве” (нахо,цится на нелегальном положении), при чем в Волковыске организация создается вновь.

Сле,дствие продолжаем в направлении установления местонахождения „Мстислава" и скрываюцихся уездных комендантов "СВБ".

О результатах сообщу.

\author{
НАРОДНЫЙ КОМИССАР \\ ГОСУДАРСТВЕННОЙ БЕЗОПАСНОСТИ \\ БЕЈОРУССКОЙ ССР (Л. ІІАНАВА) \\ (podpis)
}

„29"ь апрелі 1941 года.

№ $3 / 3 / 450$

3 Управление НКГБ - МИНСК

OTII. в 4-х экз. 
экз. № 1 - г. Москва - т. Меркулову

2 - г. Минск - т. Пономаренко

3 - в делах 3 Отдела

4 - секр. 3 Управления

Oryginal, maszynopis.

Źródło: NARB w Mińsku, zesp. 4, spr. 21, t. 2431, k. 1-3.

a Duże litery i podkreślenia oryginału.

b Dzień wpisany odręcznie.

1 Por. dok. 13.

2 Kpt. Władysław Liniarski.

3 S. Gawrychowski podaje, że „Wąsik” to pierwszy pseudonim Stanisława Cieślewskiego, ps. „Lipiec” (Por. Na placówce AK 1939-1945, Warszawa-Łomża 1997, s. 73, 98-99).

\section{Dokument 16}

1941 maj 12, Mińsk, - Informacja uzupetniajqca ministra bezpieczeństwa państwowego BSRR o aresztowanych cztonkach $Z W Z$ okręgu biatostockiego.

$3 \Pi .4$.

\section{COBEPШEHHO CEKPETHO $^{\mathrm{a}}$}

СЕКРЕТАРЮ ШК КП(б) БЕЛОРУССИИ товарищу ПОНОМАРЕНКО (Лично) гор. М и н с к

В дополнение к № 3/3/450 от 29.IV.1941 го,да ${ }^{1}$ сообщаю:

В процессе реализации намеченного плана агентурно-операционных мероприятий пІо разработке и ликвидации к/p повстанческой организации „Союз вооруженной борьбы”, установлено, что после произведенного разгрома 2-го штаба Белостокского повстанческого округа "СВБ”, оставшииеся на свободе - МИЛЕВСКИЙ, кличка „Мстислав", „Лукаш” и СТАВЕШКИЙ Стефан, кличка „ПЛЕВЕ”, внов назначили уез,дных комен,дантов и через их приступили к восстановлению связей с раионными организациями „СВБ”, подчиняя их по.д свое руководство.

В феврале месяце с.г. „Мстислав” направил в б. Шучинский уезд вновь назначенного им уездного комен,данта „Зарембо” с заданием 
создания организации „СВБ” путем новых вербовок и восстановление связей с оставпимися там участниками организации, ослабивпих контрреволюционную деятельность, в результате напих операционных у.даров .

Выполняя задание „Зарембо” прибыв в Шучинский уез,д, связался как с участниками организации, напими агентами - „Серовым" и „Шур”, после этого и „Зарембо” назначил агента „Серова" районным комендантом, поручив ему завербовать четырех гминных комен,дантов и по,дыскать конспиративную квартиру.

„Зарембо” будучи обставлен нашей агентурой, вы,дал после,дней план формирования организации, сообцив, что в целяя законспирования своего пребывания в б. Шуцинском уезде, он будет часто менять свое место нахождения, в частности в деревне Вонсоіг, вместе со своим заместителем ТАРНАЦКИМ проживает только до 23-го апреля с.г. Имея такие данные, нами 22-го апреля 1941 года „Зарембо" и ТАРНАШКИЙ были негласно сняты.

Об аресте известно липю квартирохозяйину, у которого они нахо.дились, после.цний нами завербован и соответственно проинструктирован.

В дальнейшем, проверкой через агентуру, установлено, что арест указанных лиц для участников организации неизвестен.

На ,допросе „Зарембо” назвался БУЧИНСКИМ Иваном Юзефовичем, 1914 года рождения, уроженец деревни Занюты, Плоцкого уезда, Варшавского воеводства, там же прољкивает его родственники, кадровый по,діоручик б. польской армии, ичастник польско-германской войны, пю окончанию которой проживал на нелегальном полюжении на территории БССР, являясь активным участником повстанческой организации, при себе имел воинский билет на имя Я ДЧАК Петра Томашевича.

Ранее БУЧИНСКИЙ нам был известен, как БУЖИНСКИЙ Ян, он же ЧАСКОВСКИЙ Евгений, являвппийся участником к/р повстанческой организации „ПОВ”, возглавляемой СТЕМПЕРОМ (осуж.ден), зиквидцированной в гор. Белостоке, в начале 1940 го.ца.

Далее БУЧИНСКИЙ показал, что он после ликвидации организации „ПОВ" возглавляемой СТЕМІІЕРОМ, установил связь с комен.цантом Ломжинской уез,цной организации „СВБ” - ЯЦКОВСКИМ, он же СКОВРОНЕК, кличка „Франтипек” (убит при задержании), а в после.дствии с комендантом Белостокского пाтаба „СВБ” ИГЛЕВСКИМ, кличка „Антоний” и „Нечуя”, которым был 
назначен заместителем „Франтипгка”.

В январе 1941 года „Мстислав” письменным распоряжением, через своего связного ДОМБРОВСКОГО Станислава, предложил „Зарембо” явиться к нему в деревниғо Тыборы, Замбровского района, которого затем назначил комендантом организации „СВБ” по б. Шучинскому уезду.

За время своего пребывания в б. Шучинском уезде, „Зарембо” завербовал два районных коменданта: РОГОВСКИЙ Генрик, 42 лет, поляк, плюотоновый бывпгей польской армии, кличка „Шафран” и напі агент „Серов”.

РОГОВСКИЙ получив задание от „Зарембо” о сколачевании повстанчекой организации, развернул активную деятельность. Им завербован в качестве гминного коменданта КАМИНСКИЙ, капрал бывпей польской армии, по,ц кличкой „Окунь”.

Кроме того установлена связь с капралом бывпей польской армии ГОДЛЕВСКИМ Станиславом, являюпцися активным участником организации, под кличкой „Блыскавица”, которого „Зарембо” назначил гминным комендантом с подчинением РОГОВСКОМУ.

Наря,ду с выпеизложенным 19 апреля с.г. арестован комендант „СВБ” по Белостокскому уезду - БРУ ИИСКИЙ Вла,цислав Войтехович, 1915 го.ц рождения, по,цпоручик бывпей польской армии, в пропглом комендант „СВБ” по гор. Ломжа, по.д кличкой „Оскарь”. БРУЛИНСКИЙ после его назначения на Белостокский уез,ц, обосновался в деревне Засточье, Кныпинского района, где был установлен напиим агентом „Ванька”, после чего и арестован.

Обыском у БРУЛИНСКОГО из'ьят документ на имя ДОМБРОВСКОГО Казимира Войтеховича и ря,д документов организации, копии которых при этом прилагаю ${ }^{2}$.

Из числа из'ьятых документов, характерным является специально выработанная форма ежемесячного рапорта, где предусмотрена необходимость изучения состояния, размещения войсковых частей Красной Армии, с указанием местности, № № частей, рода войск, фамилий командиров, наличия оружия, боеприпасов, количественный состав бойцов в частях и их настроения.

Одновременно обращается внимание на изучение настроения гранж,данского населения с по,дразделением польского и белорусского.

БРУЛИНСКИЙ на следствии дал развернутые показания о своей практической антисоветской деятельности. 
Из показаний „ЗАРЕМБО” и „ОСКАРА”, а также из'ьатых документов, стало известно, что после разгрома второго пітаба „СВБ”, Iроизоплла организационная перестройка и на уезды были назначены следуюоцие коменданты:

По Белостокскому уезду - „Оскарь”

" Шучинскому ", - „Зарембо"

" Соколковскому " - „Босый"

", Волковыскому ", - „Плева"

" Јомжинскому " - „Вонсик" 4

", Бельскому ", „Кусы" 5

Агентурно-следственным путем установлено, что связь уездных комендантов с „Мстиславом" осуществляется через „цепочку” связных „Мстислава”, находяццихся на нелегальном положении, в частности через личного его ад'ьютанта ЗЕЈИНСКОГО Яна, кличка „Велориб”, ЗАЛУСАГО Стефана и других.

По данным агентуры известно, что совместно с ЗЕЈИНСКИМ Яном скрывается один из содержателей явочных квартир - КУЈЕШ Вацлав (убийца сотрудника УНКГБ тов. СУРИСМАНА).

Намеченный план агентурно-оперативных мероприятий по разработке и ликвидации к/р повстанческой организации „Союз вооруженной борьбы" продолжаем реализовать.

О результатах сообщу.

IРИЛІОЖЕНИЕ: копии из'ьатых документов на $6^{\text {b }}$ листах

$$
\begin{gathered}
\text { НАРОДНЫЙ КОМИССАР } \\
\text { ГОСУДАРСТВЕННОЙ БЕЗОПАСНОСТИ } \\
\text { БЕЈОРУ ССКОЙ ССР (Ј. IІАНАВА) } \\
\text { (podpis) }
\end{gathered}
$$

„12" с мая 1941 го.да.

№ $3 / 3 / 555$

3 Управление НКГБ - МИНСК

Отп. в 4-х экз.

1 - т. Меркулову

1 - т. Пономаренко

1 - делгах 3 Отделг

1 - секр. 3 Управления 
Oryginał, maszynopis.

Źródło: NARB w Mińsku, zesp. 4, spr. 21, t. 2431, k. 54-59.

a Duże litery i podkreślenia oryginału.

b Liczba wpisana odręcznie.

c Dzień wpisany odręcznie.

1 Por. dok. 15.

2 Wymienione kopie dokumentów znajdują się w t. 2431, k. 60-65.

3 Pseudonim nie rozszyfrowany. Według polskich źródeł komendantem obwodu był od 1940 r. ppor. Stefan Doliński, ps. Tytus.

4 Por. przypis 3 przy dok. 15.

5 Mjr Jan Tabortowski.

\section{Dokument 17}

1941 czerwiec 3, Mińsk, - Informacja uzupetniajq̨ca ministra bezpieczeństwa państwowego BSRR o ZWZ w okręgu biatostockim.

\section{COBEPIIEHHO CEKPETHO ${ }^{a}$}

СЕКРЕТАРЮ ШК КП(б) БЕЛОРУССИИ товарищу ПОНОМАРЕНКО гор. М И Н С К

В дополнение к № $3 / 3 / 555$ от $12 / 5$ - 41 ${ }^{1}$ сообщаю:

$\mathrm{B}$ процессе дальнейшей реализации плана агентурно-операционных мероприятий по разработке и эиквидации к/p повстанческой шпионской террористической организации „Союз вооруженной борьбы” стало известно, что руководство „СВБ” в лице коменданта „МСТИСЛАВА” и члена штаба „ПЛЕВЕ”, несмотря на значительный разгром организации по прежнему продолжают антисоветскую деятельность в направлении расширения и укрепления организации, конспирируя свое место нахождения частыми переездами из одной местности в другую.

В данное время установлено, что организация „СВБ” изменила свое название и в настояшее время именуется „ПОВ”, что в расшифровке означает „Польская Организация Вольности” (свобо,ды экономической). 
Это изменение находит свое подтверж,дение в приказах, по,дписанных „МСТИСЛАВОМ", которые нами перехвачены через агентуру.

В настоящее время „СВБ” - „IІОВ”, стремиться к об'ьединению повстанческих организаций с прогерманской организацией, в о.дну организацию под названием „IIOB”.

Арестованный нами 11 мая 1941 го,да, нахо,дивпиийся на нелегальном положении комендант к/p шпионской терропистической организации „Батальон смерти”, по Бельскому обводу - IIIВЕД Э.двар.д-Ришард Иванович, кличка „СЕНДЕВОЙ”, 1904 года рождения, поляк, подпоручик разерва б. польской армии, на допросе показал, что во второй полювине апреля с.г. будучи в г. Брянске (Белостокская область) он установил связь с комендантом „СВБ” по Бельскому уез.ду по кличке „КУСЫЙ”, который ссылаясь на получение распоряжение из Варпгавы об об'ьединении всех повстанческих организации существующих на территории б. Польпии в новую организацию, именующую себя „IIОВ”, предложил IIIВЕДУ войти в месте с организацией в "СВБ”- „IОВ" 2.

Отнесплись с недоверием к „КУСОМУ” в вопросе объединения, IIВЕД- „СЕНДЕВОЙ” потребовал от него подтверждения сказанного кем либо из членов окружного штаба, после чего „КУСЫЙ” связал ІІІВЕДА-СЕНДЕВОГО” с „МСТИСЛАВОМ".

При встрече с „МСТИСЈАВОМ” ІІІВЕ-„СЕНДЕВОЙ” дал согласе на об'ьединение руководимой им к/р организации „Батальон смерти” с организацией „Союз вооруженной борьбы” по,д общим руково.дством „МСТИСЈ АВА”.

Из беседы с „КУСЫМ” и „МСТИС А АОМ” ІІІВЕД-„СЕН ДЕВОЙ” узнал, что организацей „ІІОВ” руководит только польское правительство и что „IIOВ” абсолютно не связан с гестапо.

Кроме того „КУСЫЙ” сообщил IIВЕДУ, что реорганизация "СВБ” в „ІІОВ" вызвана сложившейся безнадежной междунаро.дной обстановкой, в которой исключается возможнность восстановления Польши, как самостоятельного государства и поэтому перед организацией „IIОВ” стоит задача облегчить жизнь полякам путем по,дготовки людей на должнности коммунальных, кооперативных и а.дминистративных учереждений.

Из сообщения „КУСОГО” Шведу, что руково.дство „СВБ” в завуалированном ви,де об'ьасняет необходимость реорганизации "СВБ”, якобы, сложкивпейся межкдународной обстановкой, а фак- 
тически является маневром германской разведки, руководящей деятельностью $\mathrm{k} / \mathrm{p}$ польских националистических организации на нашей территории ${ }^{3}$.

Показания ШВЕДА- „СЕНДЕВОЙ” в части присоединения руководимого им обвода „Батальон Смерти” к „Союзу вооруженной барьбы" подтерждаются перехваченными нами через агентуру приказом № 4 коменданта округа „C” датированном 10 мая 1941 го,да за подписью „МСТИС ЈАВА”.

Этим же приказом Швед-„СЕН ДЕВОЙ” назначалгя в качестве заместителя комен,данта „СВБ” по Бельскому уез,ду.

Поступивпими за после,днее время агентурными данными устанавливается, что окружной комен,дант - „МСТИС ЈАВ” вновь намерен соз,дать повстанческую организацию „СВБ”- „ІІОВ” в гор. Белостоке.

В этих целях „МСТИСЈАВ” дал задание „IІЈЕВЕ” поддыскать офицера на должность комен,данта по городу Белостоку.

„IIJEBE” встретившись с напим источником „АЈЕКС”, являющимся заместителем комен,данта „СВБ” по Белюстокскому уез,цу, в беседе с последним об улучшении работы в Белостокском повете (уезде) заявил, что ему тяжело работать с „МСТИСЛАВОМ” потому, что он часто требует представления рапортов, отчетов, сообщений, которые требуют много времени и подвергают опасности деконспирировать организацию.

„IIJЕВЕ” недоволен методами работы „МСТИСЈАВА”.

В дальнейшей беседе с источником „IIJIEBE” сообщил, что с Варшавским центром связь ослабла и до сих пор для пітаба округа не могут получить денег.

Из перехваченных нами документов организации, видно, что тактика „СВБ” несколько изменилась и сводится к следующему:

1. Практически „СВБ” объединяется с к/р повстанчесой, ппионской террористической организацией „Батальон смерти”, руково.димой агентом германской разведки в Варшаве КОНЕЧНЫМ.

2. Руководство повстанческим подпольем исходит из близости войны между Германией и СССР, в связи с чем намечают из своей среды лиц, которые долюны бу,дут представлять германскую власть на местах.

3. Специальной инструкцией окружного комен,данта „СВБ” предусмотрена связь с ксендзами и информация последних о повстанческой ,деятельности. 
4. Установка окружного пІтаба „СВБ” приблизить к себе белоруссов расчитывая на них как на резерв в борьбе против Советской власти, воздерживаясь гока от прямой вербовки их.

5. Активные методы борьбы с Советской властью в виде организованного саботажа.

Реализация плана агентурно-операционных мероприятий по разработке и ликвидации „СВБ” продолжаем.

ПРИЛОЖЕНИЕ: Документы организации на „31” листах ${ }^{4}$.

$$
\begin{gathered}
\text { НАРОДНЫЙ КОМИССАР } \\
\text { ГОСУДАРСТВЕННОЙ БЕЗОПАСНОСТИ } \\
\text { (podpis) (Л. ШАНАВА) }
\end{gathered}
$$

3 июон 1941 года

№ $3 / 3 / 740$

МИНСК

Oryginal, maszynopis.

Źródło: NARB w Mińsku, zesp. 4, spr. 21, t. 2432, k. 16-20.

\footnotetext{
${ }^{a}$ Duże litery i podkreślenia oryginału.

1 Por. dok. 16.

2 Chodzi o akcję scaleniową, lecz nie $\mathrm{z}$ organizacjami proniemieckimi.

${ }^{3}$ Informacja nieprawdziwa.

${ }^{4}$ Kopie dokumentów znajdują się w wymienionej teczce k. 21-51.
} 


\section{Dokument 18}

1941 czerwiec 9, Mińsk, - Informacja specjalna ministra bezpieczeństwa państwowego BSRR o aresztowaniu cztonków kierownictwa $Z W Z$ w okręgu biatostockim.

COBEPIIEHHO CEKPETHO $^{a}$ только лично

СЕКРЕТАРЮ ЦК КІ(б) БЕЈОРУССИИ ТОВАРИЩУ IIOHОМАРЕНКО

\section{II Е I C O O Б III Е H И E}

В дополнение наших № № 2/2462 от 7 марта и 3/3/555 от 12 мая с.г. ${ }^{1}$ донопу, что после двукротного разгрома Белостокской Окружной Организации СВБ (Союз вооруженной борьбы) и ареста его руководителей „АНТОНИЯ”, „Стефана”, „БУРИ”, СПЕХАЈІЬСКОГО и других, руководство Белостокской окружной организации возглавил присланный из Варпавы от Главного ШІтаба - Коменды „МСТИСЈАВ”, который назначил заместителем себя СТАВЕШКОГО Стефана Яновича, жкителя территории Германии, бывпего поручика польской армии, под кличкой „IIJIEBA”.

„IIJЕВА” со дня организации в Белостокском округе СВБ был бессменным начальником пІтаба этой организации.

В результате проведенных нами агентурных мероприятий, стало нам известно, что „IJIEВА” в последнее время должен был восстановить разгромленную повстанческую организацию по Белостокскому округу. Для этой цели он связялся с напим агентом „AJIEKC", при помощи которого в ночь на 9 июня с.г. „ШJЕВА” в Белостокском районе, недалеко от селения Тыкоцин секретно был захвачен организованной нами засадой.

По напим агентурным данным, а также и со слов арестованного „IJIEВA" известно, что „IIJЕВА” был недоволен работой руководителя организации - „МСТИСЈАВА”, поэтому „ІІЛЕВА” принял репение после проведения организационной работы по Белостокскому уезду, выехать в Варпіаву к Главному коменданту генералу РОВЕЦКОМУ („РАКОНЬ”) с докладом о плохой работе „МСТИСЛАВА" и предложением его замены. 
„II ЛЕВА" нами ,допрашивается для его полного разоблачения, после чего мољна бу,дет решить вопрос о его вербовке в целях захвата в наши руки всей деятельности Белостокской по,цпольной окружной организации СВБ, а такље каналов связи с варшавским центром.

О.дновременно принимаем меры для захвата руководителя организации „МСТИСЈАВА”.

О результатах донесу.

\section{НАРОДНЫЙ КОМИССАР ГОС. БЕЗОІІАСНОСТИ (podpis) ( $Л$. IIAHABA)}

„9"ь июоня 1941 г.

№ $3 / 3 / 790$

г. Минск

Oryginał, maszynopis.

Źródło: NARB w Mińsku, zesp. 4, spr. 21, t. 2432, k. 90-91.

a Duże litery i podkreślenia oryginału.

b Dzień wpisany odręcznie.

1 Por. dok. 13 i 16. 


\section{Dokument 19}

1941 czerwiec 9, Mińsk, - Informacja specjalna ministra bezpieczeństwa państwowego BSRR o agenturalnym rozpracowaniu członków ZWZ $w$ obwodzie grajewskim (szczuczyńskim).

\section{COBEPIEHHO CEKPETHO $^{a}$}

СЕКРЕТАРЮ ШК КП(б) БЕЛОРУССИИ (Лично) г. М и н с к

\section{$\underline{\mathrm{C} I I} \mathrm{E} \amalg \mathrm{C} O \mathrm{O}$ Б $\amalg \mathrm{E} H \underline{\mathrm{U}}$}

По данным агента УНКГБ Белостокской Области „ЩУР”, работаюпего по разработке учестников к/р повстанческой организации "Соғоз вооруженной борьбы”, сталю известно, что к нему 23 мая с.г. явился участник организации „СВБ” - БУКОВСКИЙ Викетий и обратился с просьбой устроить на два дня якобы прибывпии из Августовского уезда двух неизвестных и содействовать им в дальнейпгем в про,движении по марпіруту ими указанному.

Обрацаясь с просьбой к „Щуру” БУКОВСКИЙ о прибывпих неизвестных никаких установочных данных не сооблцил.

Неизвестные встретились с агентом „ШУР” и заявили ему, что они от "МСТИСЛАВА", одновременно сообщили „ЩУРУ", что „МСТИСЈАВ назначил его комендантом Щучинского уез,ца, т.к. б. комендант „ЗАРЕМБА” арестован:

Получив такие данные от „ЩУРА”, нами был разработан план негласного ареста неизвестных, по которому были немечены мероприатия исключающие распи фровку агента „ЩУР”.

Осуцествление полностью плана помепгала внезапная болезнь агента „ЩУР”, однако это способствовало болыпой его запифровки. Для выполнения намеченных мероприятий в Граевсий РО НКГБ была направлена оперативная группа в составе 8 человек, которая обнаружила неизвестных на хуторе, вблизи д. Климапевница, на чердаке дома СКИТОВСКОГО Витольда Марценовича.

Как установлено в дальнейлем, в указанной дом неизвестные были направлены комендантом пл.яцувки .д. Климапевница через одного из участников повстанческой организации.

На предлозжение неизвестным сдаться, последние по оперативной 
группе открыли огонь и бросили гранату.

Преследуя цель взать преступников живыми, на чер.дак дома, с предлозкением с.даться несколько раз посылалась хозяйка дома, однако и после этого неизвестные продолэкали отстреливаться.

Спустя некоторые время огонь со стороны неизвестных прекратился.

Посланная на чер.дак хозяйка дома сообщила, что оба неизвестных убиты.

Осви,дительствование военно-медицинской экспертизы показало, что они застрелились.

Обыском у неизвестных обнарузкено и изъато: 2 боевых граната, 2 пистолета и к ним 6 патрон, 2 карты, компас и один военный билет на имя НАЙГРО.ДСКОГО Ивана Викетевича, 1903 го.да рождения, выданный Чижевским РВК Белостокской области.

Убитые были сфотографированы и при предцявлениғо их фото арестованным: „Зарембо”, и „Оскру”, последние в убитых опознали участников организации:

1. ПОПЛАВСКИЙ Станислав (имя не точно) - комен,дант гмины повстанческой организации „СВБ”, по кличке „Рожановский” , проживал в деревне Жабиково, Снядовского района, последнее время находился на нелегальном положении.

2. КОНЮШИ Станислав (имя не точно) являлгся одним из руководителей Ломжинской уез,цной повстанческой организации, в которой руководил разведкой, имел кличку „Ястщемб”, был связан с комендантом Белостокского штаба „СВБ” - „МСТИСЛАВОМ” , после.днее время находился на нелегальном положении, известный нам по показаниям арестованных участников организации: ЗАБОРОВСКОГО Чеслава Аброзевича, ЗАЛУПКОГО Та,деуша Э.двардовича и .других.

Данные показания арестованных „Зарембо” и „Оскара”, нами уточнянотя через другие источники.

$$
\begin{gathered}
\text { НАРОДНЫЙ КОМИССАР } \\
\text { ГОСУ.ДАРСТВЕННОЙ БЕЗОПАСНОСТИ } \\
\text { (podpis) (Л. ІІАНАВА) }
\end{gathered}
$$

Отп. в 4-х экз

№ 1 - т. Меркулюву

№ 2 - т. Пономаренко 
№ 3 - делгах 3 От,ц.

№ 4 - секр. 3 Отд.

„9"ь июня 1941 г.

№ $3 / 3 / 791$

3 Управление НКГБ-Минск

Oryginał, maszynopis.

Źródło: NARB w Mińsku, zesp. 4, spr. 21, t. 2432, k. 92-95.

a Duże litery i podkreślenia oryginału.

b Dzień wpisany odręcznie.

\section{Dokument 20}

1941 czerwiec 14, Mińsk, - Informacja specjalna ministra spraw wewnętrznych BSRR o wynikach dziatań operacyjnych skierowanych przeciwko ZWZ obwodu tomżyńskiego.

COBEPIIEHHO CEKPETHO $^{a}$

$\Gamma \mathrm{T}$.

СЕКРЕТАРЮ ШК КП(б) БЕЛОРУССИИ товарищу ПОНОМАРЕНКО гор. М и н с к

\section{СЩЕЩСООБЩЕНИЕ}

Шо данным агента УНКГБ Белостокской области - „МАТРОС”, работающего по разработе участников к/р повстанческой организации „Союз вооруженной борьбы” сталю известно, что 6 июня с.г. в г.Ломжу прибыл комендант к/р повстанческой организации по Ломжинскому уезду - ЦЕСЕЛЬСКИЙ Станислав Антонович, кличка „ВОНСИК”, который поручил источнику „Матрос” установить в предмести города Ломжи учителя ФРАНУС Франтипка, кличка „БЕЛЗА” и вызвать его 13 июня сего года к себе на квартиру для переговоров с „ВОНСИК”.

„БЕЛЗА” был назначен „Оскаром" (арестован) в качестве заместителя уездного коменданта и комендантом организации „СВБ” по горо,ду Ломжа. 
Днем 13 июня сего года, в дом источника „МАТРОС” (ранее был комендантом плютона в городе Јомжа) прибыл „ВОНСИК” и „БЕЛЗА”.

„ВОНСИК” в разговоре подтвердил о назначении „БЕЛЗА заместителем уездного коменданта и комендантов „СВБ” по городу Јомљка, а источника „МАТРОС" назначил членом пाтаба к/р повстанческой организации „СВБ” по гор. Јомэка.

В дальнейней беседе „ВОНСИК” дал указание о развороте работы повстанческой организации в городе ЈІомже и назвал при этом трех комендантов плютонов. Договоривпись о методах связи, обещал в ближайпие дни прислать приказ и инструкцию о работе.

По выходе из квартиры источника, в городе „ВОНСИК” был негласно снят и доставлен в УНГБ Белостокской области.

Обыском у „ВОНСИК” из'ьат пाифр. ФРАНУС, Франтипек по операционным соображениям пока не арестовывается. Допрос "ВОНСИК" ведем в направлении установления практической к/p деятельности „ВОНСИК” за время его пребывания в ЈЈожинском уезде.

О результатах сообщу.

\section{НАРОДНЫЙ КОМИССАР ГОСУДАРСТВЕННОЙ БЕЗОІІАСНОСТИ БЕЛОРУССКОЙ ССР (podpis) ( $Л$. IIAHABA)}

„14" ь июня 1941 года

№ $3 / 3 / 843$

Oryginał, maszynopis.

Źródło: NARB w Mińsku, zesp. 4, spr. 21, t. 2432, k. 129-130.

a Duże litery i podkreślenia oryginału.

b Dzień wpisany odręcznie. 


\section{ANEKSY}

\section{Aneks 1}

\section{Wykaz wykrytych przez NKWD organizacji podziemnych} w obwodzie białostockim w okresie grudzień 1939-lipiec $1940^{1}$

\section{Liga do walki z komunizmem i bezbożnictwem. Liczyła} 38 członków. Działała w Białymstoku. Uczestniczyli w niej byli członkowie OZONU, Młodej Polski i duchowieństwo. Rozwijała działalność propagandową wymierzoną w ustrój komunistyczny i radzieckie władze. Wykryta w grudniu 1939 r.

2. Stronnictwo Narodowe. Grupa liczyła 5 członków. Działała w pow. wysokomazowieckim i skupiała członków dowojennego Stronnictwa Narodowego. Prowadziła działalność wśród ludności polskiej i przygotowywała zbrojne powstanie przeciwko władzy radzieckiej. Wykryta w grudniu 1939 r.

3. Młodzieżowa Organizacja Powstańcza. Liczyła 40 członków. Działała w Białymstoku i powiecie białostockim. Jej struktura opierała się na systemie „piątkowym”. Na czele organizacji stał komendant. Przygotowywała zbrojne wystąpienie przeciwko władzy radzieckiej. Odebrano uzbrojenie: 27 granatów i 685 szt. amunicji. Wykryta w grudniu 1939 r.

4. Polska Organizacja Powstańcza. Liczyła 40 członków. Działała w Białymstoku. Jej struktura opierała się na systemie „dziesiątkowym”. Na czele stał komendant. Skupiała „polskich nacjonalistów”. Przygotowywała się do wystąpienia zbrojnego w momencie wznowienia działań wojennych. Wykryta w styczniu 1940 r.

5. Organizacja Powstańcza. Liczyła 38 członków. Działała w rejonie łomżyńskim. Jej struktura opierała się na systemie „piątkowym”. Zadaniem organizacji było przygotowanie powstania zbrojnego przeciwko władzy radzieckiej. Wykryta w lutym 1940 r.

6. Akcja Katolicka. Grupa liczyła 47 członków. Działała w rejonie ciechanowieckim. Miała swoje komórki w terenie. Prowadziła działalność antyradziecką, m.in. organizowała masowe wystąpienia ludności w obronie aresztowanego księdza. Wykryta w lutym 1940 r. 
7. Młodzieżowa Organizacja „Niezawisłość Polski”. Liczyła 8 członków. Działała w Łomży. Jej struktura opierała się na systemie „piątkowym". Rozpowszechniała ulotki i przygotowywała powstanie zbrojne przeciwko władzy radzieckiej. Odebrano ulotki oraz powielacz. Wykryta w lutym 1940 r.

8. Organizacja „POW”. Liczyła 16 członków. Działała w rejonie śniadowskim. Jej struktura opierała się na systemie „piątkowym”. Miała łączność z warszawskim sztabem powstańczym. Przygotowywała zbrojne wystąpienie przeciwko władzy radzieckiej. Wykryta w marcu 1940 r.

9. Organizacja „POW”. Liczyła 33 członków. Działała w Łomży. Jej struktura opierała się na systemie „piątkowym”. Przygotowywała wystąpienie zbrojne. Wykryta w marcu 1940 r.

10. Organizacja „Wojsko Polskie”. Liczyła 89 członków. Działała w Łomży i Śniadowie. Struktura organizacji oparta została na zasadach obowiązujących w wojsku polskim. W jej skład wchodzili wyłącznie wojskowi, głównie podoficerowie. Zadaniem organizacji była walka $\mathrm{z}$ władzą radziecką. Odebrano broń: 2 karabiny maszynowe, 26 karabinów, 5 rewolwerów i 6000 szt. amunicji. Wykryta w marcu 1940 r.

11. Młodzieżowa organizacja „Partyzantka”. Liczyła 26 członków. Działała w Wołkowysku. Zorganizowana przez młodzież szkolną starszych klas według systemu „dziesiątkowego". Przygotowywała się do powstania zbrojnego przeciwko władzy radzieckiej. Wykryta w marcu 1940 r.

12. Organizacja powstańcza. Liczyła 21 członków. Działała w Wolkowysku. W jej skład wchodzili głównie podoficerowie wojska polskiego. Przygotowywała się do powstania zbrojnego przeciwko władzy radzieckiej. Wykryta w marcu 1940 r.

13. Organizacja „Batalion śmierci”. Liczyła 19 członków. Działała w pow. wysokomazowieckim. Zbudowana była na zasadach obowiązujących w wojsku polskim. Powstała $z$ inicjatywy wileńskiego sztabu powstańczego. Wykryta w kwietniu 1940 r.

14. Organizacja powstańcza. Liczyła 17 członków. Działała w Sokółce. Zorganizował ją obszarnik Szyszko. Prowadziła działalność dywersyjną w jednostkach Armii Czerwonej. Miała swoje organizacje w terenie. Przygotowywała się do zbrojnych wystąpień. Odebrano broń: 11 karabinów, 2 rewolwery, 25 strzelb myśliwskich, 11 szabel i 165 szt. amunicji. Wykryta w kiwetniu $1940 \mathrm{r}$.

15. Polska Organizacja Wojskowa. Liczyła 152 członków. Działała w Grodnie, miała też swoje oddziały w Białymstoku, Baranowiczach, Brześciu, Pińsku i Lwowie. Powołana została przez ośrodek warszawski na zle- 
cenie polskiego rządu we Francji. Utrzymywała też łączność z ośrodkiem wileńskim. Jej struktura opierała się na systemie „dziesiątkowym”. Sztab dzielił się na 5 oddziałów: wywiadowczy, dywersyjny, gospodarczy, wojskowy i sanitarny. Działała pod hasłem: „Każdy Polak-Katolik - członkiem organizacji". Prowadziła działalność dywersyjną skierowaną przeciwko aktytwowi partyjno-radzieckiemu. Odebrano uzbrojenie: 1 karabin maszynowy, 40 karabinów, 50 granatów, 3 bomby lotnicze, 4949 szt. amunicji, 14 strzelb myśliwskich, 17 bagnetów, 23 rewolwery i 330 szt. amunicji do nich oraz maski przeciwgazowe, materiały wybuchowe i zamki do karabinów maszynowych. Wykryta w kwietniu 1940 r.

16. Organizacja „POW”. Zorganizowana podobnie jak organizacja grodzieńska. Skupiła 95 członków. Wykryta w kwietniu 1940 r.

17. Tajna Organizacja Polska. Liczyła 29 członków. Stanowiła filię organizacji młodzieżowej. Zbudowana była w systemie „piątkowym”. Wykryta w kwietniu 1940 r.

18. Organizacja „POW”. Liczyła 58 członków. Działała w Augustowie i w Puszczy Augustowskiej. Stanowiła filię „POW”. Odebrano broń: 1 ciężki karabin maszynowy, 28 karabinów, 48 granatów i 5395 szt. amunicji. Wykryta w maju $1940 \mathrm{r}$.

19. Polska Armia Powstańcza (PAP). Liczyła 46 członków. Działała w Łomży, według zasad obowiązujących w wojsku polskim. Organizacją kierował sztab rejonowy. Wykryta w maju 1940 r.

20. Organizacja „PAP”. Liczyła 9 członków. Działała w rejonie zambrowskim. Stanowiła część organizacji łomżyńskiej. Wykryta w maju 1940 r.

21. Organizacja „Młoda Wieś”. Liczyła 12 członków. Działała w rejonie białostockim. Zorganizowana przez młodzież szkolną na zasadzie „piątkowej”. Przygotowywała się do powstania zbrojnego przeciwko władzy radzieckiej. Wykryta w maju 1940 r.

22. Związek Walki Zbrojnej. Grupa liczyła 14 członków. Działała w Białymstoku. W jej skład wchodzili głównie podoficerowie wojska polskiego. Przygotowywali się do powstania zbrojnego. Wykryta w czerwcu $1940 \mathrm{r}$.

23. Rosyjska organizacja „białych emigrantów” (ROWS). Liczyła 18 członków. Powołana przez oficerów rosyjskich „białej” emigracji. Przygotowywała się do powstania zbrojnego przeciwko władzy radzieckiej. Wykryta w czerwcu 1940 r.

24. Organizacja „Partyzantka”. Liczyła 35 członków. Działała w Jedwabnem. Zorganizowana przez podoficerów wojska polskiego. Przygotowy- 
wała się do obalenia władzy radzieckiej w wyniku powstania zbrojnego. Wykryta w czerwcu 1940 r.

25. Przerzutowa organizacja („Piereprawocznaja”). Liczyła 14 członków. Działała na linii Lida-Małkinia. Zajmowała się przerzutem przez granicę i łącznością z ziemiami polskimi okupowanymi przez Niemców. Wykryta w czerwcu $1940 \mathrm{r}$.

26. Organizacja „Szare Szeregi”. Grupa liczyła 8 członków. Działała w Białymstoku na zasadach obowiązujących w harcerstwie. Przygotowywała się do powstania. Wykryta w czerwcu 1940 r.

27. Organizacja „Wojsko Polskie”. Liczyła 96 członków. Powstała w październiku-listopadzie 1939 r. w pow. łomżyńskim. Działała na zasadach obowiązujących w wojsku polskim. Organizacją kierował okręgowy sztab w Łomży, któremu podlegały sztaby rejonowe. Odebrano broń: 1 ciężki karabin maszynowy, 3 działka przeciwlotnicze, 9 karabinów, 11 granatów, 6 rewolwerów, 8 bagnetów, 2000 szt. amunicji oraz aparat telefoniczny i materiały opatrunkowe. Wykryta w lipcu 1940 r.

28. Organizacja „POW". Liczyła 80 członków. Działała w Augustowie i stanowiła filię POW. Odebrano uzbrojenie: 1 karabin maszynowy, 30 karabinów, 10 szabel kawaleryjskich, 43 bagnety, 3568 szt. amunicji, 48 granatów. Oprócz tego wykryto magazyn z materiałami przeznaczonymi do dywersji, w którym było: $6 \mathrm{~kg}$ trotylu, 1 bomba zapalająca, 1 spłonka, 6 m sznuru Biksforda i inny sprzęt. Wykryta w lipcu 1940 r.

29. Związek Walki Zbrojnej. Organizacja liczyła 79 członków. Działała w rejonie białostockim i jedwabieńskim. Zorganizowana była na zasadzie „piątkowej”. Przygotowywała powstanie zbrojne przeciwko władzy radzieckiej. Wykryta w lipcu 1940 r.

30. Organizacja „Partyzantka”. Liczyła 8 członków. Działała w rejonie białostockim. Przygotowywała się do przejścia do lasów i prowadzenia walki zbrojnej z władzą radziecką. Wykryta w lipcu 1940 r.

Źródło: NARB w Mińsku, zesp. 4, spr. 21, t. 2078, k. 137-152.

1 Wykaz powyższy stanowi tłumaczenie informacji przekazanej w dniu 27 VII $1940 \mathrm{r}$. przez ministra spraw wewnętrznych BSRR I Sekretarzowi KC KP(b)B P. Ponomarence. Część statystyczną tej informacji zawiera tabela 2. Przy nazwach organizacji podano dosłownie ich tłumaczenie. Pominięto jedynie przymiotniki „kontrrewolucyjna”, w części też „powstańcza”. Tabela 2 i niniejszy wykaz stanowią całość informacji o organizacjach w obwodzie białostockim. Nie jest to pełny wykaz wykrytych przez NKWD organizacji. Czesść informacji jest nieścisła, np. w augustowskim chodzi zapewne o organizację PAW a nie „POW”. 


\section{Aneks 2}

Kopia przetłumaczonego na język rosyjski meldunku J. Prawdzica-Szlaskiego do KG ZWZ, przejętego przez NKWD podczas aresztowania w dniu 21 lutego $1941 \mathrm{r} .{ }^{1}$

В след за моим рапортом от дня 5/1, 1 доношу, что про.должано вести работу в округе Сукно ${ }^{2}$ Ког.да мы вместе с MATEEM $^{3}$ сюо.да прибыли, мы нашли организованными: повят Ломжа, Выско-Мазовецк, частично Бельск и (о,дно слово неразборчивп). После того, как мы привели их в поря.цок К.Г. (Комендант Глувны), в настояцце время я организую повят г. Белосток, повят Щучин, Гродно. Остальные места округа и области не тронуты.

Работа тяжелая, потому что условия с квартирами и комуникацией очень тяжелые. Даже самые лучпие документы и алиби не играют ни какой роли, а только личное счатье и глубокое знание отнопений и приобретенный опыт на этой специфической территории могут обеспечить безопасность для жизни и свободного передвижения. В приграничных дереанях и в зоне три,дцать километров сидит специальный человек, который следит за деревней, нахо.дится ли там или не приехал ли чужой человек. Крестьяне по.ц угрозой высылки должны доложить о чужих людяя.

Из тюрмы вернулся - ОБТУЛОВИЧа , по,дписал декларацию сотрудничества. Сообіцил об этом и якобы удралг ожидая приказа К.Г., который его отзовет. В после.цние .цни арестовали несколько человек из его контактов в Горо.дно. Дело очень загадочное.

На территории Львова у нас работает в пользу больпевиков ГУЛЯ. ПОВАЛА отказывается от напей организации и перешол на сторону Львовской группы, которая стоит против сего,днявшего напгего правительства. Деньги полученные К.Г., он присвоил себе. Групны эту я стараюсь разбить.

При по.дборе новых людей для этой территории прошу помнить: Bсе внов прибывпиие должны пока что приспособливаться к указа- 
ниям людей из этой территории, вопрос полномочий сле,дует разрешать с каждым отдельным человеком команды, а также следует определить об'ьем работы каждого в отдельности и всякие перемены, которые могут возникнуть в связи с убылью отдельных членов и.т.д.

Костюмы команды должны быть лучшие - разницы никакой нет (без экстраваганции): Нет людей на руководящие работы.

Я предусматриваю гор. Вильно, как место нахождения будущего птаба территории, условие самое лучшее (нет границ).

Мое мнение - следует территорию 2 присоединить к Вильно, создавая там соответствуюпий пттаб.

Якобы в ближайпие дни должны об'ьявить советской ІІолыпу. Армию взял на себя создать генерал - Янушайтис, вербую офицеров из лагерей. ЈТагерия - Козельский и Старобельский поделены на малые группы. В Москве сидит генерал ГЛУХОВСКИЙ, ЛАНГЕР и СПиСОВИЧ.

ІІрошу прислать круглую печать к документам и их пломбирку, которые я я Варшаве дал - ШЕСЛЯКУ (МАКАРОН), а также спросить его, что с паспортами, которые он делал в согласии со мной.

ІІереведено с польского языка. Переводчик УНКВД Белостокской обл. /ЮХНОВСКАЯ /

ПРИМЕЧАНИЕ: Настоящий документ не закончен по причине того, что ШУЛЬШ в момент исполнения этого документа был арестован.

\section{ВЕРНО: НАЧАЈЬНИК 2 ОТДЕЛА НКГБ БССР \\ Мл. лейтенант Госбезопасности (СМОЈьНИКОВ) (podpis)}

$\underline{7^{\mathrm{b}} \text { марта } 1941 \text { го.да }^{\mathrm{c}}}$

Na dole trójkątna pieczęć z napisami: w środku „УГБ”, a w otoku „Haро.цный Комиссариат Внутренных .Дел БССР. 2-й Отдел УГБ”.

Oryginal, maszynopis.

Źródło: NARB w Mińsku, zesp. 4, spr. 21, t. 2434, k. 36-39.

a Duże litery oryginału.

b Dzień wpisany odręcznie.

c Jest to da ta sporządzenia meldunku NKWD, do którego załączono tłumaczenie raportu J. Szulca. 
1 J. Szulc pisze o okolicznościach przejęcia przez NKWD meldunku: „Pamiętam jak dziś, pisałem meldunek do Komendy Głównej, gdy gospodyni moja, p. Wołejkowa, wpadła nagle do pokoju krzycząc, że bolszewicy idą. Zdążyłem tylko zniszczyć meldunek gdy wpadło ich trzech z mauserami do pokoju. Dom był obstawiony. Rzucono mnie na tapczan i zaczęto rewidować". Prawdopodobnie meldunek został przez NKWD odtworzony ze strzępów rękopisu. (Por. J. Prawdzic-Szlaski, Nowogródczyzna w walce. 1940-1945, Londyn 1976, s. 22).

2 Kryptonim okręgu białostockiego ZWZ-AK. 